\title{
REVIEW OF NitRogen FATE MODELS APPLICABLE TO FOREST LANDSCAPES IN THE SOUTHERN U.S.
}

\author{
D. M. Amatya, C. G. Rossi, A. Saleh, Z. Dai, M. A. Youssef, R. G. Williams, D. D. Bosch, \\ G. M. Chescheir, G. Sun, R. W. Skaggs, C. C. Trettin, E. D. Vance, J. E. Nettles, S. Tian
}

\begin{abstract}
Assessing the environmental impacts of fertilizer nitrogen ( $N$ ) used to increase productivity in managed forests is complex due to a wide range of abiotic and biotic factors affecting its forms and movement. Models developed to predict fertilizer $N$ fate (e.g., cycling processes) and water quality impacts vary widely in their design, scope, and potential application. We review the applicability of five commonly used eco-hydrologic models (APEX, MIKESHE-DNDC, DRAINMOD-FOREST, REMM, and SWAT) in assessing $N$ fate and transport in southern forest landscapes $\left(<50 \mathrm{~km}^{2}\right)$ because of their comprehensiveness and multi-scale predictions. The field-scale models DRAINMOD-FOREST and REMM contain process-level components characterizing hydrology, forest growth, and $N$ dynamics, but they have limited capability to describe transport processes at the landscape scale. APEX can describe hydrology, forest growth, $N$ fate processes, and plant competition at the landscape and small watershed scales mostly for upland. SWAT is best suited to hydrologic simulations at watershed scale $\left(>50 \mathrm{~km}^{2}\right)$, although $N$ routing below the subbasin level does not yet exist. Similarly, the distributed MIKESHE-DNDC model has been used to assess $N$ cycles across different spatial scales, on both uplands and lowlands, but was not intended to model lateral N transport. However, MIKESHE alone is capable of describing the hydrology and $N$ transport. The strengths of each of the models reflect their original design and scope intent. Based on this review, none of the five models that we considered is independently adequate to address the fate of $N$ fertilizers applied to forest stands at both small and large scales, including uplands and lowlands. While efforts are underway to extend these tools' capabilities and address their various limitations, the models must be validated using experimental data before using their outputs, together with uncertainty analysis, for developing forest fertilization guidelines and the fate and

Submitted for review in January 2013 as manuscript number SW transport of $N$.
\end{abstract} 10096; approved for publication by the Soil \& Water Division of ASABE in September 2013.

Mention of trade names or commercial products in this publication does not imply recommendation or endorsement by the USDA. The USDA is an equal opportunity provider and employer.

The authors are Devendra M. Amatya, ASABE Member, Research Hydrologist, USDA Forest Service, Center for Forested Wetlands Research, Cordesville, South Carolina; Cole G. Rossi, Regional Water Quality Specialist and Salinity Coordinator, Bureau of Land Management, National Operations Center, Salt Lake City, Utah; Ali Saleh, ASABE Member, Professor and Associate Director, Texas Institute for Applied Environmental Research, Tarleton State University, Stephenville, Texas; Zhaohua Dai, Former Research Scientist, University of New Hampshire, Durham, New Hampshire; Mohamed A. Youssef, ASABE Member, Associate Professor, Department of Biological and Agricultural Engineering, North Carolina State University, Raleigh, North Carolina; Randall G. Williams, ASABE Member, Research Engineer, and David D. Bosch, ASABE Member, Research Hydrologist, USDA-ARS Southeast Watershed Research Laboratory, Tifton, Georgia; George M. Chescheir, ASABE Member, Research Associate Professor, Department of Biological and Agricultural Engineering, North Carolina State University, Raleigh, North Carolina; Ge Sun, Research Hydrologist, USDA Forest Service, Eastern Forest Environmental Threat Assessment Center, Raleigh, North Carolina; R. Wayne Skaggs, ASABE Fellow, WNR and Distinguished University Professor, Department of Biological and Agricultural Engineering, North Carolina State University, Raleigh, North Carolina; Carl C. Trettin, Research Soil Scientist and Team Leader, USDA Forest Service, Center for Forested Wetlands Research, Cordesville, South Carolina; Eric D. Vance, Principal Scientist, National Council for Air and Stream Improvement (NCASI), Inc., Research Triangle Park, North Carolina; Jami E. Nettles, Hydrologist, Timberlands Technology, Weyerhaeuser Company, Columbus, Mississippi; and Shiying Tian, Postdoctoral Scientist, Department of Biological and Agricultural Engineering, North Carolina State University, North Carolina. Corresponding author: Devendra Amatya, USDA Forest Service, Center for Forested Wetlands Research, 3734 Highway 402, Cordesville, SC 29434; phone: 843-336-5612; e-mail: damatya@fs.fed.us.
Keywords. APEX, C:N ratio, DRAINMOD-FOREST, Hydrologic processes, In-stream process, MIKESHE-DNDC, Nitrogen transport, Productivity, REMM, SWAT.

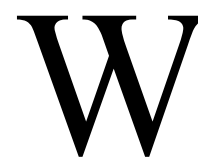
idespread use of fertilizer in pine forests of the southeastern U.S. is a primary reason for substantial increases in their productivity in recent decades (Fox et al., 2007). These forest lands provide important ecosystem services (Prestemon and Abt, 2002), but questions have been raised about the potential effects of forest fertilizers on hydrology and water quality, including nutrient and sediment concentration in downstream ecosystems (Beltran et al., 2010; Grace et al., 2007; Amatya et al., 2006). The 2000 National Water Quality Inventory (NWQI) report (USEPA, 2002) does not conclude that forestry is a leading source of water impairment in the U.S., and evidence suggests that forest fertilization is only a minor contributor to water and air quality impairment, particularly in the context of agricultural and urban uses (USEPA, 1995; Wahl et al., 1997; Tufford et al., 2003; Muller and Spahr, 2006; Amatya and Skaggs, 2011). Due to the large area of forests that are increasingly fertilized under intensive management regimes, land managers, policymakers, and industries are interested in understanding the mechanisms controlling $\mathrm{N}$ sources, sinks, and its ultimate fate (Tian et al., 2012a). Understanding of $\mathrm{N}$ fate and transport is needed to further develop fertilizer and other 
management prescriptions that increase fertilizer use efficiency and reduce environmental impacts. The factors affecting $\mathrm{N}$ forms and transport in managed forest ecosystems are complex due to a wide range of abiotic and biotic factors, including the amount, type, and timing of fertilizer applied, hydrologic conditions, vegetation type, the geochemistry of forest soils, and previous and current disturbances and applications (Anderson, 2002). A schematic of forest ecosystem processes is shown in figure 1.

Tracking $\mathrm{N}$ forms and related processes is particularly difficult in riparian areas where their width, hydrologic pathways, topographies, and soils vary greatly with physiographic and climatic gradients from the coastal plains to the mountainous uplands. Relationships between forests and water quality indices are well documented (Ice and Stednick, 2004; Binkley et al., 2004), but questions remain regarding the impact of silvicultural activities on water resources. Despite the demonstrated effectiveness and widespread use of voluntary forestry best management practices (BMPs) (Ice et al., 2010; NCASI, 2009), public questions and concerns are manifested in the development of total maximum daily load (TMDL) provisions and a citizen suit (Northwest Environmental Defense Center v. Brown, 640 F.3d, 9th Cir. 2011) that resulted in a U.S. Ninth Circuit Court decision that runoff from logging roads is subject to National Pollution Discharge Elimination System (NPDES) permits. That decision was overruled by the
U.S. Supreme Court (Decker v. Northwest Environmental Defense Center, 11-338, 2013), and the Phase I Stormwater Regulations were modified by the EPA (40 CFR 122.26(b)(14), EPA-HQ-OW-2-12-0195) to clarify the fact that logging road runoff is not an industrial point-source discharge subject to permitting requirements.

Most fertilizer fate studies have been conducted at the plot scale (Cough et al., 2004; Sampson et al., 2006; Will et al., 2006) with a limited assessment of soil-water pathways. Catchment-scale water quality assessment has not typically measured components of the $\mathrm{N}$ balance with sufficient resolution to assess the $\mathrm{N}$ fate mechanisms in forested ecosystems, and only a few studies have attempted to combine these two approaches to describing $\mathrm{N}$ fate and lateral transport (Hwang et al., 2009). While considerable research has been done on the physiological effects of fertilization of loblolly pine (Pinus taeda L.) (Sampson et al., 2006; Will et al., 2006; Cough et al., 2004; Murthy and Dougherty, 1997; Vose and Allen 1991; Tietema, 2004; Koskela, 2000; Ducey and Allen, 2001), fewer catchmentscale studies have investigated the effects of fertilization on streamwater nutrient concentrations (Binkley et al., 1999; McBroom et al., 2008; Beltran et al., 2010).

An understanding of in-stream flow and nutrient routing, transport, and transformation including the effects of channel morphology, composition, and biota is also needed in addressing questions about the effects of forest fertilization

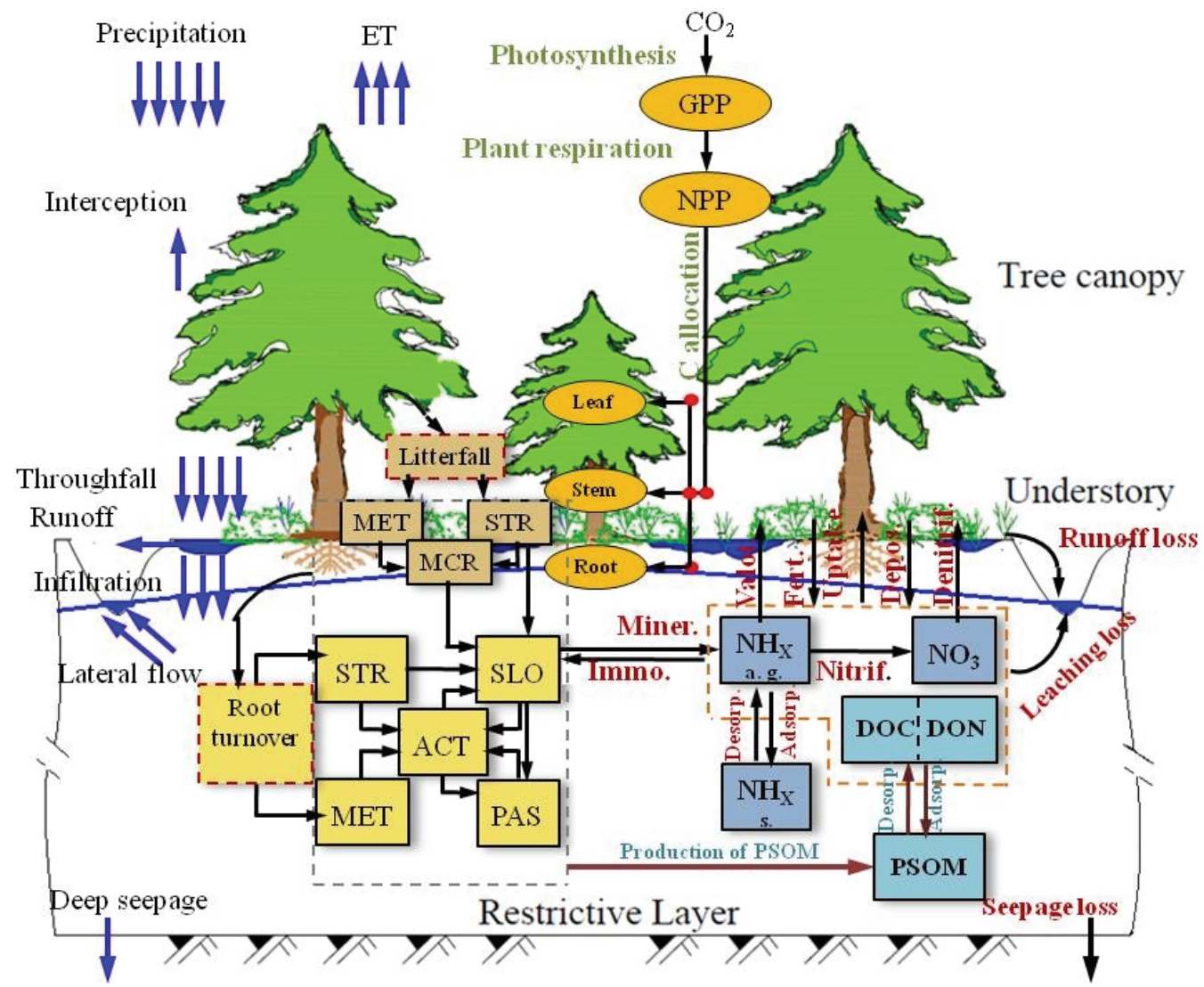

Figure 1. Hydrological and biogeochemical processes in a typical drained forest ecosystem. Soil organic matter pools: STR = structural pool, MET $=$ metabolic pool, MCR $=$ microbial pool, $A C T=$ active pool, SLO $=$ slow pool, and PAS $=$ passive pool . Nitrogen cycling: Volat $=$ volatilization, Fert $=$ fertilization, Depos $=$ air deposition, Denitrif $=$ denitrification, Immo $=$ immobilization, Miner $=$ mineralization, Nitrif $=$ nitrification, Adsorp = adsorption, and Desorp = desorption (after Tian et al., 2012b). 
practices on nutrient movement and cumulative impacts on receiving waters. This will require comprehensive, watershed-scale $\mathrm{N}$ cycling and transport studies that cover the complete forest life cycle, from establishment to harvest. However, the complexity of sources and controlling processes in large watersheds potentially limits understanding at these scales (Alexander et al., 2002).

An ideal model for reliably addressing impacts of fertilization in forested lands in the southeastern U.S. on $\mathrm{N}$ fate and transport in downstream receiving waters at a landscape or small watershed scale $\left(\sim 50 \mathrm{~km}^{2}\right)$ should account for the following:

- Dominant hydrologic processes (interception, canopy and soil/litter evaporation, transpiration, surface runoff and subsurface drainage) of the forests characteristic of the southeastern U.S.

- Understory ET processes, especially from harvest to overstory canopy closure (Sampson et al., 2011; Powell et al., 2005).

- All phases of $\mathrm{N}$ cycling belowground and aboveground, the relationship to soil $\mathrm{C}$, and transport processes in soil water (fig. 1).

- Tree growth and productivity.

- Silvicultural management practices.

- Hydrologic and $\mathrm{N}$ cycling processes in riparian buffers (fig. 2).

- In-stream transformation, and water and $\mathrm{N}$ flux transport and routing from individual field or subcatchment outlets to streams and rivers or estuaries (figs. 1 and 2).

- Nitrogen use in the context of the $\mathrm{N}$ cycle accounting for $\mathrm{N}$ loss mechanisms, especially after fertilization (fig. 1), as pointed out by Schlesinger (2009) and Delgado (2002).

This article is the outcome of a workshop on "Challenges in Modeling the Fate of Nitrogen Applied to Forests" held at the USDA Forest Service Center for Forested Wetlands Research at the Santee Experimental Forest, South Carolina, which focused on the current state-of-theknowledge, strengths, and limitations of five widely used models: APEX, DRAINMOD-FOREST, MIKESHE-DNDC, REMM, and SWAT.

\section{LITERATURE REVIEW}

A wide range of models have been developed to simulate and understand $\mathrm{N}$ fate and transport mechanisms at different spatial and temporal scales in both agricultural and forested ecosystems (e.g., Aber et al., 2005; Saleh et al., 2004; Li et al., 2004b; El-Sadak et al., 2003; Styczen and Storm, 1993; Lunn et al., 1996; El-Kadi and Ling, 1999; Gusman and Marino, 1999; Ling and El-Kadi, 1998; Johnson et al., 2000; Yuan et al., 2003; Shaffer, 1995). Most $\mathrm{N}$ fate and transport models have been developed for agricultural lands. In this article, we review simulation models that have been applied to forest ecosystems based on type, scales, levels of complexity, and functionality.

\section{Forest Growth (ProduCtivity) Models}

Most recently, Tian (2011) conducted an extensive literature search of 25 forest ecosystem and productivity models with different levels of complexity. Among these models, PnET (Aber and Federer, 1992; Aber et al., 1996, 1997), 3-PG (Landsberg and Waring, 1997), FORESTBGC (Running and Coughlan, 1988; Running and Gower, 1991) and its successor BIOME-BGC (Running and Hunt, 1993), and G'DAY (Comins and McMurtrie, 1993) were found to be more comprehensive and less data-intensive productivity models. Most of these individual forest growth models are limited in their water and nutrient cycling processes with comparable level of details that are available when describing the life cycle of a managed forest.

\section{N CYCLING MODELS}

$\mathrm{NuCM}$ (Johnson et al., 2000) is a stand-level model that has been applied in upland conditions for simulating the cycling of $\mathrm{N}, \mathrm{P}, \mathrm{K}, \mathrm{Ca}, \mathrm{Mg}$, and $\mathrm{S}$ processes on daily, weekly, or monthly time scales. NuCM has been applied to several forest ecosystems (ponderosa pine, red spruce, beech, eastern deciduous, loblolly pine, slash pine, Scots pine, and

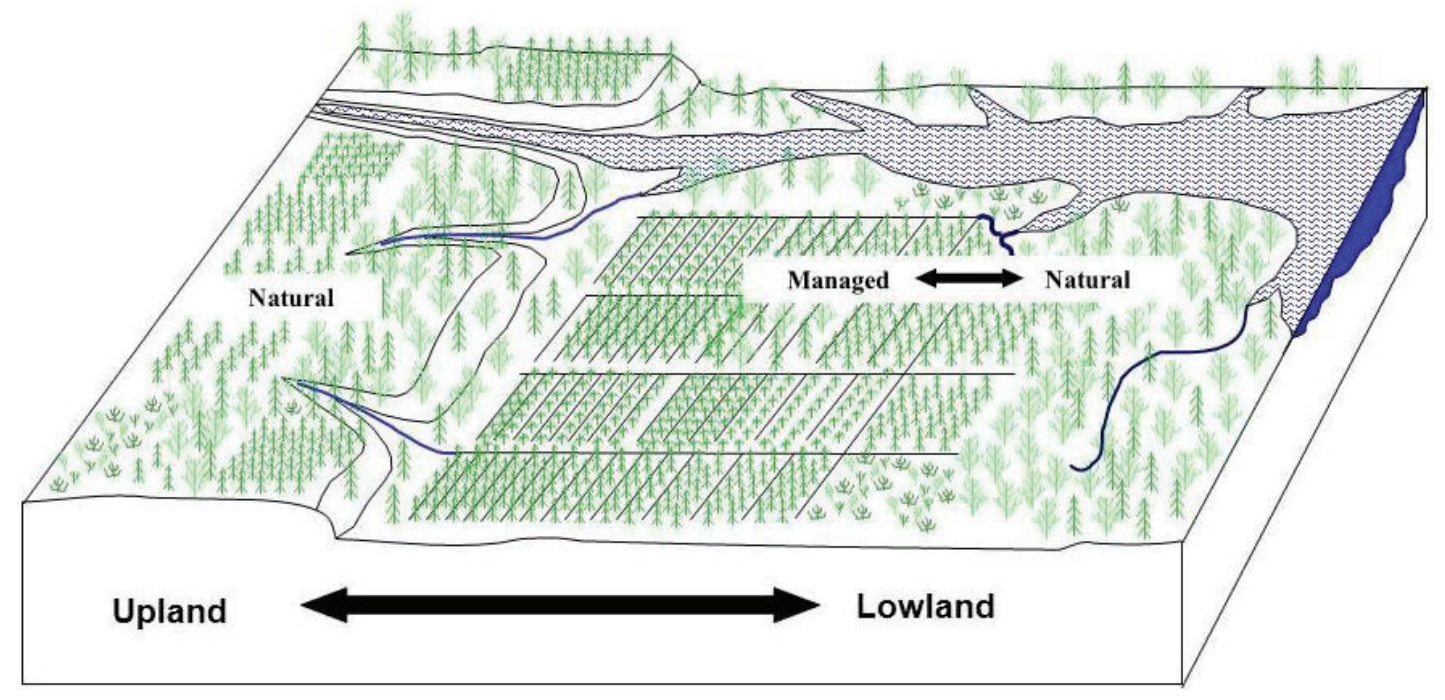

Figure 2. Schematic of ditches, canals, and stream draining a forest landscape. 
Norway spruce) to simulate the effects of changing atmospheric deposition, harvesting, species change, precipitation quantity, increased temperature, elevated $\mathrm{CO}_{2}$, and liming. Model output has matched field data well in harvesting applications and liming treatments. A review of $\mathrm{NuCM}$ applications (Johnson et al., 2000) concluded that the model is more successful in matching decadal-scale changes in nutrient pools and soils and less successful in capturing intra-annual variations in soil solution chemistry. The $\mathrm{NuCM}$ model has provided insight into forest ecosystems, including the potential for short-term soil alterations and the importance of nutrient translocation in $\mathrm{N}$ cycling.

Koskela (2000) developed a biogeochemistry-based plant growth process model for grass-stage pine seedlings in Thailand. Using a Monte Carlo simulation method for model parameter sensitivity, within-shoot shading and specific $\mathrm{N}$ uptake rate of fine roots were found as the two most significant parameters affecting model performance.

Ducey and Allen (2001) used NUTREM, a simplified model of $\mathrm{C}$ and $\mathrm{N}$ uptake and distribution, to simulate tenyear macronutrient budgets for 14 installations in a regionwide mid-rotation loblolly pine plantation (Pinus taeda L.). The accuracy of NUTREM is limited by the availability of basic process-level data.

\section{WATER AND N CYCLING MODELS}

The field-scale biogeochemistry model DAYCENT (Del Grosso et al., 2001) is a daily time step version of the CENTURY model (Parton et al., 1994). DAYCENT has been used to quantify $\mathrm{N}$ pools and annual streamflow and mineral $\mathrm{N}$ export at the subwatershed level at HubbardBrook Experimental Forest (HBEF) in New Hampshire (Li et al., 2004b). A DAYCENT version linked to SWAT (Arnold et al., 1998) extended the simulation of $\mathrm{N}$ export to the large watershed scale ( $\mathrm{Li}$ et al., 2004b). It was determined that as much as $480 \mathrm{~kg} \mathrm{ha}^{-1}$ of $\mathrm{N}$ was stored in forest litter, soil organic matter (SOM), and plant living biomass. Net $\mathrm{N}$ mineralization of SOM and forest litter contributed $93 \%$ of total available $\mathrm{N}$ for export within the HBEF forest ecosystem that did not receive any fertilization application.

Tietema (2004) developed an empirical and processbased model (WANDA, a regional N model With Aggregated Nitrogen DynAmics) linked with a simple forest hydrology model (SWIF, Soil Water In Forests; Tiktak and Bowten, 1992) to predict $\mathrm{N}$ concentrations and fluxes from 350 forest stands draining to the Edese Bos catchment in the Netherlands. The WANDA model is built around the concept that nitrate losses from forests are linked to the $\mathrm{C}: \mathrm{N}$ ratio of the organic layer. Although drainage water nitrate concentrations were successfully predicted by the linked model, improvements in the water flux component would be required to accurately simulate total nitrate fluxes.

Lauren et al. (2005) developed a two-dimensional model (FEMMA) to describe water and $\mathrm{N}$ fluxes, including $\mathrm{NH}_{4}-$ $\mathrm{N}, \mathrm{NO}_{3}-\mathrm{N}$, and dissolved organic nitrogen (DON), from a first-order forested catchment before and after its clearcutting, by linking its processes along a hillslope to the stream segment. The authors found that microbial immobilization, uptake by vegetation, and soil sorption were the major sinks of $\mathrm{N}$ after clearcutting. Most of the $\mathrm{N}$ export took place during the spring flood, when plant $\mathrm{N}$ uptake was minimal. The export of $\mathrm{N}$ to streams is controlled by complex physical, chemical, and biological interactions, with nitrification being a key factor. Lauren et al. (2005) cited models that have been used to describe catchment water and $\mathrm{N}$ dynamics, e.g., Magic and its versions (Jenkins et al., 2001), SOILN (Eckersten and Beier, 1998), SMART and its versions (Ahonen et al., 1998), MERLIN (Kjonaasn and Wright, 1998) and PNet-CN/CHESS (Postek et al., 1995). In these models, water and $\mathrm{N}$ fluxes for a forest or an entire catchment are calculated in a vertical column of soil divided into horizontal layers, or the modeling domain is described as a set of interconnected storages with no dimension specified. None of these models account explicitly for DON fluxes even though this flux can comprise $80 \%$ to $90 \%$ of stream exports of TN. Tian et al. (2012a) found precipitation and drainage to be the dominant controlling factors for annual DON exports, but not for temporal variations.

Sampson et al. (2006) presented a rotation-length hybrid process model (SECRETS-3PG) that was calibrated (using control treatments) and verified (using fertilized treatments) using daily estimates of water and C fluxes, canopy leaf area, and annual estimates of tree growth and dimension for loblolly pine stands in North Carolina.

\section{WATER AND Nitrogen CyCling Models WITH IN-STREAM TRANSPORT}

In-stream transport and transformation models using a variety of deterministic, statistical, and hybrid methods have been used to model $\mathrm{N}$ transport in river basins (Alexander et al., 2002); the authors reviewed the accuracy of six empirical and quasi-empirical watershed models (excluding SWAT or HSPF; Johanson et al., 1981) of N export with varying levels of spatial resolution and stream process complexity for use in large watersheds. Breeman et al. (2002) reported $\mathrm{N}$ budgets for 16 large watersheds in the northeastern U.S., including both published data and results from these empirical and process models. The authors quantified the fate of $\mathrm{N}$ inputs using independent storage and loss estimates. Denitrification from land was estimated from the difference between all inputs and all other storage and loss terms. Similarly, in-stream transport models of various levels of complexity were developed for flow and nutrient routing in canals and streams (fig. 3) and linked with DRAINMOD models for assessing the watershedscale impacts of $\mathrm{N}$ transport in coastal pine forests (Fernandez et al., 2002, 2005, 2006, 2007; Amatya et al., 2004).

Johnson and Gerald (2006) discussed current efforts at the U.S. Army Engineer Research and Development Center (ERDC) to develop a watershed-scale water quality model that incorporates detailed cycling processes for $\mathrm{N}, \mathrm{P}$, and associated material, such as sediment and organic matter within soil, water, and vegetation. Unlike available nonpoint-source models like SWAT and HSPF, the ERDC developed nutrient submodules (NSM) to represent the fate and transport processes of nutrients within and among soils, on the overland surface, and in channel systems. These NSMs are integrated into complex and physically based 


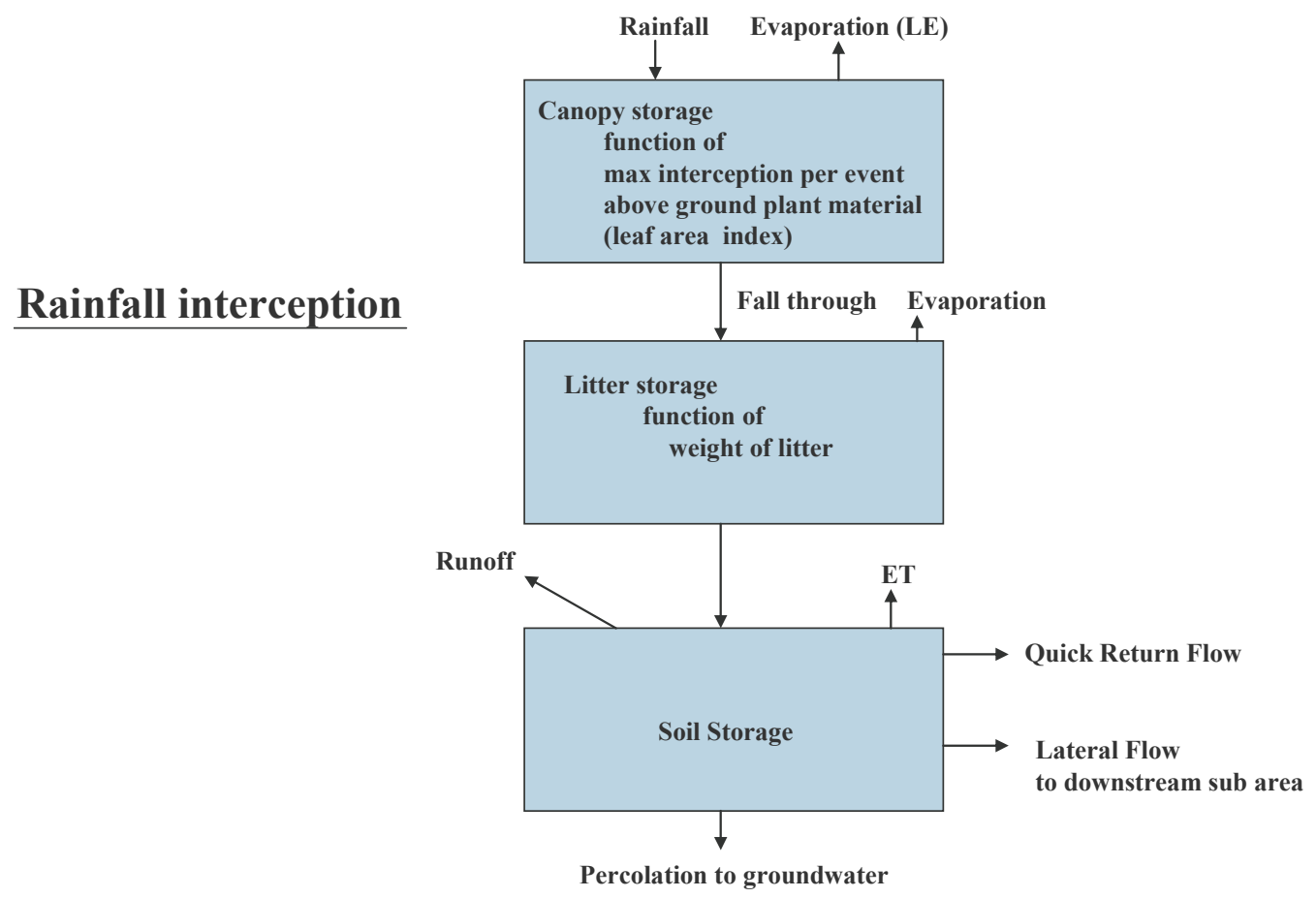

Figure 3. APEX modification for forestry condition.

hydraulic and hydrologic modeling systems to achieve detailed transport between and across various hydrologic regimes.

Most recently, Abdelnour et al. (2011) developed a spatially distributed eco-hydrological model, Visualizing Ecosystems for Land Management Assessments (VELMA), to simulate changes in soil-water infiltration and redistribution, ET, surface and subsurface runoff, $\mathrm{C}$ and $\mathrm{N}$ cycling in plants and soils, and the transport of dissolved forms of $\mathrm{C}$ and $\mathrm{N}$ from the terrestrial landscape to streams. The authors demonstrated how hillslope and catchment-scale processes control stream discharge in a small Pacific Northwest catchment.

There are other models (e.g., APEX, MIKESHE-DNDC, DRAINMOD-FOREST, REMM, and SWAT) that have been widely used by research institutions, including forest industries, for predicting and assessing $\mathrm{N}$ fate and transport and $\mathrm{C}$ cycling in upland and lowland forest ecosystems in the southeastern U.S., although REMM is primarily used for riparian ecosystems. MIKESHE-DNDC is a recently linked model and is reviewed in this assessment for completeness. These models offer the greatest promise in comprehensiveness and multi-scale prediction for forest ecosystem; therefore, they are discussed in depth as central to this review's assessment described below.

\section{OBJECTIVES}

The main objectives of this review are (1) to develop a synthesis of the existing knowledge on the characteristics, hydrologic and biogeochemical processes, model inputs and outputs, assumptions, uncertainties, applications, and limitations of five commonly used hydrology and water quality models (APEX, MIKESHE-DNDC, DRAINMODFOREST, REMM, and SWAT) and (2) to explore the potential and feasibility for compiling or developing a comprehensive modeling system for addressing $\mathrm{N}$ fate (cycling processes) and transport following fertilization of a forested landscape with an operational size of about 5000 ha (50 $\mathrm{km}^{2}$ ) in the southeastern U.S.

\section{Methodology}

We characterized and evaluated five commonly used hydrology and water quality models, presented in table 1 , for a synthesis with respect to general features (e.g., structure, scale, and scope), hydrologic processes, $\mathrm{C}$ and $\mathrm{N}$ cycling, productivity (tree growth), management practices, input and output parameters, and uncertainty analysis. Modeling approaches, assumptions, data requirements and gaps, capabilities, strengths, and limitations for addressing questions related to the fate, cycling, and transport of fertilizer $\mathrm{N}$ across a range of forested sites and management regimes were evaluated. 
Table 1. Comparative features of types, processes simulated, strengths, weaknesses, applications, and limitations of five hydrology and water quality models for forest nitrogen cycling (fate) and transport. ${ }^{\text {al }}$

\begin{tabular}{|c|c|c|c|c|c|}
\hline Model Features & APEX & MIKESHE-DNDC & DRAINMOD-FOREST & REMM & SWAT \\
\hline Developers & $\begin{array}{l}\text { Williams, Izaurralde, } \\
\text { Dyke, and Jeong; } \\
\text { USDA-ARS GSWRL } \\
\text { and Texas A\&M Uni- } \\
\text { versity }\end{array}$ & $\begin{array}{l}\text { DHI (2005) for } \\
\text { MIKESHE; C. Li at } \\
\text { University of New } \\
\text { Hampshire for DNDC, } \\
\text { and Z. Dai at USDA } \\
\text { Forest Service }\end{array}$ & $\begin{array}{c}\text { R. W. Skaggs for } \\
\text { DRAINMOD; S. Tian } \\
\text { and M. Youssef for } \\
\text { DRAINMOD-FOREST, } \\
\text { North Carolina State } \\
\text { University (NCSU) }\end{array}$ & $\begin{array}{l}\text { USDA-ARS } \\
\text { SEWRL, } \\
\text { Tifton, Ga. }\end{array}$ & $\begin{array}{l}\text { Arnold and } \\
\text { Williams, } \\
\text { USDA-ARS } \\
\text { GSWRL, } \\
\text { Temple, Tex. }\end{array}$ \\
\hline $\begin{array}{c}\text { Field and/or } \\
\text { watershed scale }\end{array}$ & $\begin{array}{c}\text { Field and small } \\
\text { watershed; HRU } \\
\text { or grid-based }\end{array}$ & $\begin{array}{l}\text { Watershed; HRU } \\
\text { or grid-based }\end{array}$ & $\begin{array}{c}\text { Field; neither grid } \\
\text { nor HRU-based }\end{array}$ & $\begin{array}{l}\text { Field; similar to } \\
\text { HRU-based }\end{array}$ & $\begin{array}{l}\text { Large watershed; } \\
\text { HRU-based }\end{array}$ \\
\hline Forest land use & $\begin{array}{l}\text { Yes; multi-run avail- } \\
\text { able for tree growth } \\
\text { before year } X\end{array}$ & Yes & Yes & Yes & Yes and no \\
\hline Upland/lowland & Upland & Upland and lowland & Lowland & Lowland & Upland \\
\hline $\begin{array}{c}\text { Largest area applied } \\
\left(\mathrm{km}^{2}\right)\end{array}$ & 4200 & $\begin{array}{l}\text { Depends on topography } \\
\text { and geography }\end{array}$ & 480 & 0.1 & 795000 \\
\hline $\begin{array}{l}\text { Surface runoff and } \\
\text { flow generation }\end{array}$ & $\begin{array}{l}\text { CN (five types), } \\
\text { G-A (four types) }\end{array}$ & $\begin{array}{l}\text { P-B; Richard's equation } \\
\text { and kinematic wave }\end{array}$ & $\begin{array}{c}\text { P-B; surface } \\
\text { depression storage }\end{array}$ & $\begin{array}{c}\text { P-B, } \\
\text { modified G-A }\end{array}$ & $\mathrm{CN} 2, \mathrm{G}-\mathrm{A}$ \\
\hline $\begin{array}{l}\text { Subsurface flow } \\
\text { and drainage }\end{array}$ & Yes & $\begin{array}{l}\mathrm{P}-\mathrm{B} ; 3-\mathrm{D} / 2-\mathrm{D} \\
\text { linear reservoir }\end{array}$ & P-B & $\begin{array}{l}\text { P-B, mass balance } \\
\text { based on field } \\
\text { capacity }\end{array}$ & $\begin{array}{l}\text { Kinematic storage } \\
\text { lateral; GW exp. } \\
\text { BF recession }\end{array}$ \\
\hline Evapotranspiration & Five options & $\begin{array}{l}\text { P-B; PET, LAI, } \\
\text { and soil moisture }\end{array}$ & $\begin{array}{l}\text { P-B, Thornthwaite } \\
\text { or direct input }\end{array}$ & $\begin{array}{c}\text { P-B, } \\
\text { modified P-M } \\
\end{array}$ & $\begin{array}{c}\text { P-M, P-T, } \\
\text { Hargreaves } \\
\end{array}$ \\
\hline Water table dynamics & Yes & P-B & P-B & P-B, Darcy's equation & Yes \\
\hline Nitrogen $(\mathrm{N})$ cycling & Yes & P-B & P-B & P-B & Yes \\
\hline Phosphorus (P) cycling & Yes & P-B & Not Included & P-B & Yes \\
\hline Carbon $(\mathrm{C})$ cycling & Yes & P-B & P-B & P-B & Static/CFARM \\
\hline Soil erosion process & $\begin{array}{c}\text { Sheet and rill; } \\
\text { MUSLE, RUSLE, } \\
\text { RUSLE2, USLE }\end{array}$ & Not included & Not included & P-B & MUSLE \\
\hline In-stream $\mathrm{N}$ transport & Yes & No & Not included & $\begin{array}{l}\text { None, simulation ends } \\
\text { with delivery to stream }\end{array}$ & $\begin{array}{l}\text { QUAL2E/ } \\
\text { conservative }\end{array}$ \\
\hline In-stream P transport & Yes & No & Not included & $\begin{array}{l}\text { None, simulation ends } \\
\text { with delivery to stream }\end{array}$ & $\begin{array}{l}\text { QUAL2E/ } \\
\text { conservative }\end{array}$ \\
\hline In-stream C transport & Yes & No & Not included & $\begin{array}{l}\text { None, simulation ends } \\
\text { with delivery to stream }\end{array}$ & $\begin{array}{c}\text { QUAL2E/ } \\
\text { conservative }\end{array}$ \\
\hline $\begin{array}{l}\text { In-stream sediment } \\
\text { transport }\end{array}$ & $\begin{array}{c}\text { Modified } \\
\text { Bagnold's equation } \\
\text { (Bagnold, 1977) }\end{array}$ & Not included & Not included & Not included & $\begin{array}{c}\text { Modified } \\
\text { Bagnold's equation } \\
\text { (Bagnold, 1977) }\end{array}$ \\
\hline $\begin{array}{l}\text { Riparian process } \\
\text { for hydrology }\end{array}$ & Yes & Yes & Not included & P-B, same as upland & Quasi-buffers \\
\hline $\begin{array}{l}\text { Riparian process } \\
\text { for nutrient cycling }\end{array}$ & Yes & No & Not included & P-B, same as upland & Plant uptake \\
\hline Temporal scale & $\begin{array}{c}\text { Subhourly, daily, } \\
\text { monthly, annual }\end{array}$ & $\begin{array}{l}\text { Daily, monthly, } \\
\text { annual }\end{array}$ & Subhourly, daily & Daily & $\begin{array}{l}\text { Daily, monthly, } \\
\text { and annual }\end{array}$ \\
\hline Uncertainty analysis & No & No & Not yet & $\begin{array}{l}\text { Inamdar et al., } \\
\text { 1999a, 1999b; } \\
\text { Graff et al., 2005 }\end{array}$ & Yes \\
\hline Model supported by & $\begin{array}{c}\text { Texas A\&M } \\
\text { Agrilife }\end{array}$ & No & NCSU-BAE & $\begin{array}{l}\text { USDA-ARS } \\
\text { SEWRL }\end{array}$ & $\begin{array}{l}\text { USDA-ARS } \\
\text { GSWRL }\end{array}$ \\
\hline Possibility of linkage & Yes & Yes & Yes & Yes & Yes \\
\hline $\begin{array}{c}\text { Most recent } \\
\text { publications for } \\
\text { forest ecosystems }\end{array}$ & Available & $\begin{array}{l}\text { Dai et al. } \\
\text { (2012) }\end{array}$ & $\begin{array}{c}\text { Tian et al. } \\
(2012 \mathrm{~b}, 2012 \mathrm{c})\end{array}$ & $\begin{array}{l}\text { Bhat et al. } \\
\text { (2007) }\end{array}$ & $\begin{array}{l}\text { Gassman et al. } \\
\text { (2007) }\end{array}$ \\
\hline $\begin{array}{l}\text { Recent ongoing } \\
\text { work including } \\
\text { extension }\end{array}$ & $\begin{array}{c}\text { Denitrification, } \\
\text { nonlinear P Langmuir, } \\
\text { heavy metals, grazing } \\
\text { (Phygrow), Southern } \\
\text { Oscillation Index } \\
\end{array}$ & & $\begin{array}{c}\text { Linking } \\
\text { DRAINMOD-FOREST } \\
\text { with an uncertainty } \\
\text { analysis component }\end{array}$ & $\begin{array}{l}\text { Linkage to SWAT } \\
\text { (Liu et al., 2007) and } \\
\text { to AnnAGNPS (Yuan } \\
\text { et al., 2007) adding } \\
\text { pesticide component } \\
\end{array}$ & $\begin{array}{l}\mathrm{C}, \mathrm{P}, \text { pesticides, } \\
\text { almanac }\end{array}$ \\
\hline Public domain & Yes & Yes & Yes & Yes & Yes \\
\hline $\begin{array}{l}\text { Other relevant } \\
\text { information }\end{array}$ & $\begin{array}{l}\text { Plant competition, } \\
\text { halophytes, heavy } \\
\text { metal database }\end{array}$ & & & $\begin{array}{l}\text { Requires estimate of } \\
\text { upland loading }\end{array}$ & \\
\hline Contacts & $\begin{array}{c}\text { Jaehak Jeong, } \\
\text { jjeong } \\
\text { @brc.tamus.edu }\end{array}$ & $\begin{array}{l}\text { Zhaohua Dai, } \\
\text { zh_dai_2008 } \\
\text { @yahoo.com }\end{array}$ & $\begin{array}{c}\text { Mohamed Youssef, } \\
\text { Mohamed_youssef } \\
\text { @ncsu.edu }\end{array}$ & $\begin{array}{c}\text { Richard Lowrance, } \\
\text { Richard.lowrance } \\
@ \text { ars.usda.gov }\end{array}$ & $\begin{array}{c}\text { Jeff Arnold and } \\
\text { Nancy Sammons } \\
\text { jeff.arnold } \\
\text { @ars.usda.gov; } \\
\text { nancy.sammons } \\
\text { @ars.usda.gov } \\
\end{array}$ \\
\hline
\end{tabular}

[a] $\mathrm{C}=$ conceptual, $\mathrm{E}=$ empirical, G-A = Green-Ampt, $\mathrm{P}-\mathrm{B}=$ process-based, $\mathrm{P}-\mathrm{M}$ = Penman-Monteith, P-T = Priestly-Taylor, $\mathrm{Q}=$ quasi-process-based, and $\mathrm{S}=$ statistical. 


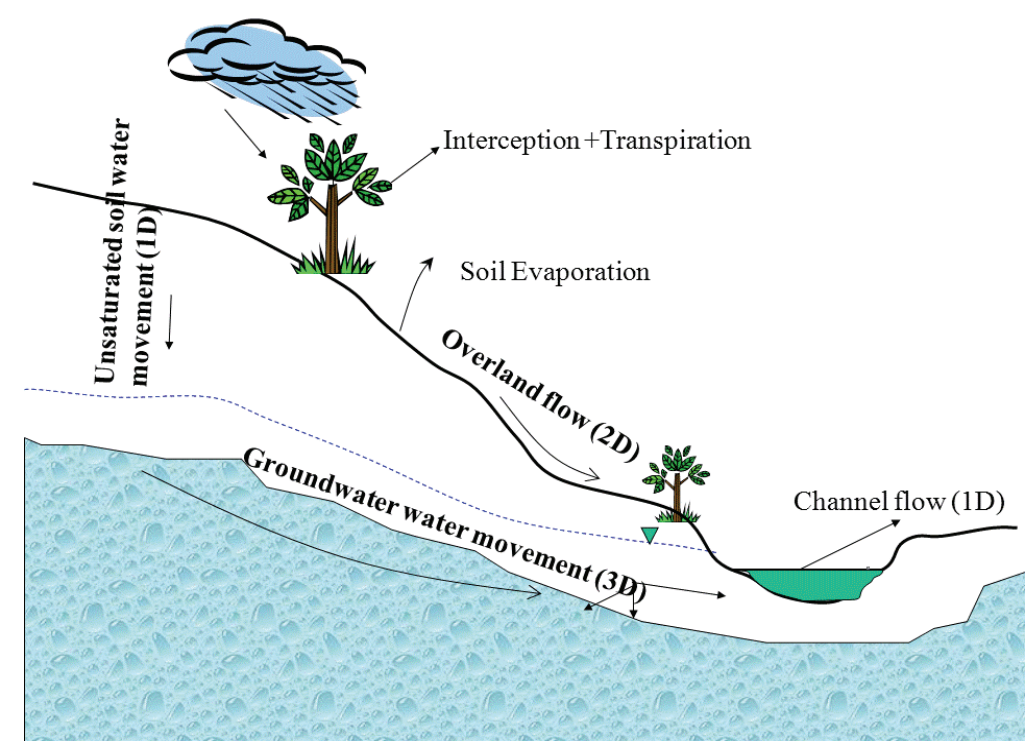

Figure 4. Schematic of processes simulated in MIKESHE (DHI, 2005).

\section{Model Evaluation APEX}

The Agricultural Policy/Environmental eXtender (APEX) model (Williams et al., 2000; Williams and Izaurralde, 2005; Gassman et al., 2005), is an extension of the Environmental Policy Impact Calculator (EPIC; Williams et al., 1984, 1989; Sharpley and Williams, 1990; Williams, 1995) for use in whole farm and small watershed management $\left(<4200 \mathrm{~km}^{2}\right)$ depending on the complexity required within the watershed. APEX was developed to evaluate various land management strategies including sustainability, erosion (e.g., wind, sheet, and stream channel), water supply and quality, soil quality, plant competition, weather scenarios, and pest control. The complete $\mathrm{N}$ cycle is simulated in APEX based on concepts used in the CENTURY model (Parton et al., 1987, 1993, 2007), including atmospheric $\mathrm{N}$ inputs, fertilizer and manure $\mathrm{N}$ applications, crop $\mathrm{N}$ uptake, denitrification, mineralization, immobilization, nitrification, ammonia volatilization, organic $\mathrm{N}$ transport with sediment, and nitrate $\mathrm{N}\left(\mathrm{NO}_{3}-\mathrm{N}\right)$ leaching losses, surface runoff, lateral subsurface flow, and tile flow. The denitrification component has been further developed by Izaurralde et al. (2006). The applicability to forested watershed conditions was enhanced (fig. 3) by modifying factors associated with forest conditions such as rainfall interception by canopy, litter, subsurface flow, nutrient movement, pesticides, and routing enrichment ratios (Saleh et al., 2004; Wang et al., 2007). The code is in the public domain.

\section{MIKESHE-DNDC}

MIKESHE (DHI, 2005) is a modularized and spatially distributed watershed hydrological model with userfriendly graphical user interfaces (GUIs) to simulate a detailed water cycle (fig. 4). Soil, vegetation dynamics, and topographic data in geographic information systems (GIS) format are used for simulation. MIKESHE has been applied to hydrologic processes in humid U.S. southeastern forest ecosystems and semi-arid regions (Tague et al., 2004; Zhang et al., 2008; Lu et al., 2009). By taking advantage of utilities that simulate the spatial variability of shallow groundwater depth, MIKESHE and Forest-DNDC, a forest ecosystem model, were loosely coupled to simulate effects of management on biogeochemical processes in forest ecosystems (Sun et al., 2006) (fig. 1). Forest-DNDC (DeNitrification - DeComposition) (Li et al., 2000) is a processbased, field-scale $\mathrm{C}$ and $\mathrm{N}$ biogeochemistry model. It simulates pine and hardwood tree growth and $\mathrm{C}$ and $\mathrm{N}$ dynamics based on energy balance, soil temperature and moisture regimes, soil C dynamics, $\mathrm{N}$ leaching, and emissions of key trace greenhouse gases (fig. 5). In contrast to the MIKESHE system that has been applied to study watershed-scale problems, Forest-DNDC has been used at field scale depending on size and topography. The model has been used for simulating water-C-nutrient dynamics for both upland ( $\mathrm{Li}$ et al., 1994, 2000) and wetland forests (Zhang et al., 2002; Li et al., 2004a; Cui et al., 2005a, 2005b; Dai et al., 2012) (figs. 1 and 2) dominated by poplar species (table 1). 


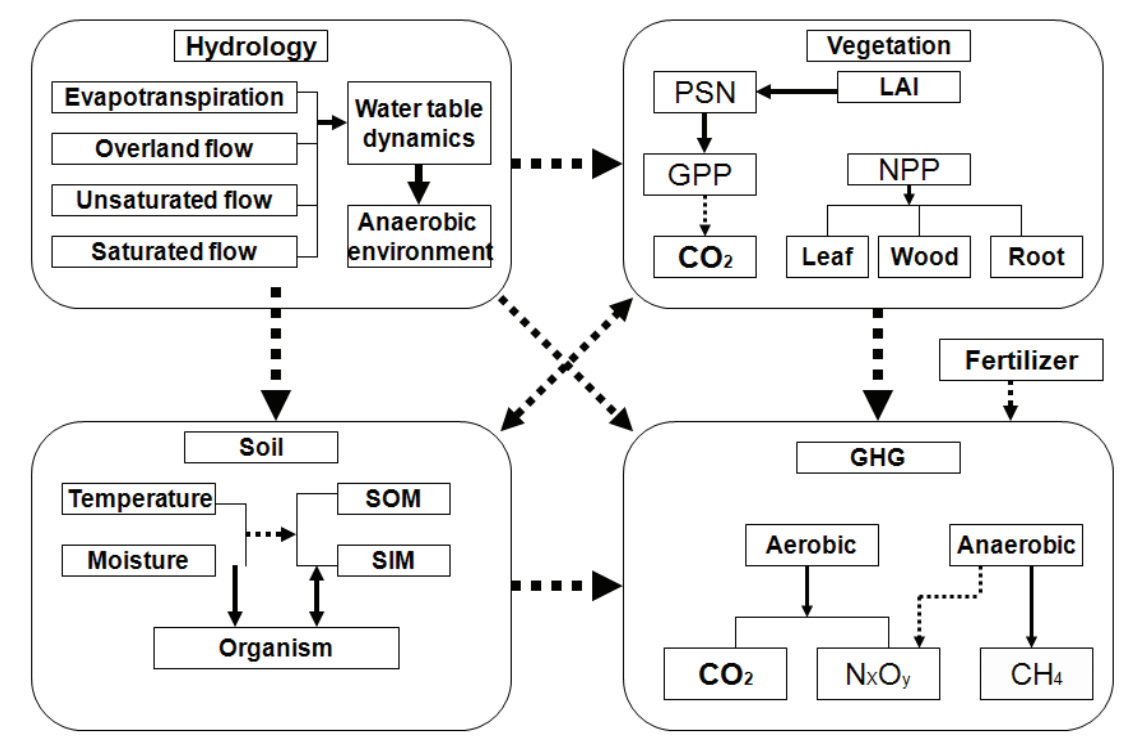

Figure 5. Wetland DNDC hydrology, physiology, and soil biogeochemistry modules.

\section{DRAINMOD-FOREST}

DRAINMOD-FOREST was developed as a stand-level forest ecosystem model to simulate the integrated hydrological, biogeochemical, and physiological processes in poorly drained forested ecosystems under various climatic conditions and management practices (fig. 1) (Tian et al., $2012 b$ ). It was developed by linking a plant growth model (mainly 3-PG) to DRAINMOD (the hydrology model) (Skaggs, 1978) and DRAINMOD-N II (the soil C and N model) (Youssef et al., 2005), both of which were originally developed for agricultural fields and slightly modified to accommodate forest ecosystems. The three components are integrated with key internal feedbacks to explicitly reflect the interactions among soil water, soil $\mathrm{C}$ and $\mathrm{N}$, and vegetation. The model has been successfully applied in simulating long-term temporal variations of plant growth, hydrological variables, and $\mathrm{N}$ (mainly nitrate) losses from three loblolly pine plantations (located in the North Carolina coastal plain) with and without intensive water management and silvicultural practices (Tian et al., 2012b, 2012c).

\section{REMM}

REMM (Lowrance et al., 2000; Altier et al., 2002) was developed for researchers and natural resource agencies as a modeling tool to quantify the water quality benefits of riparian buffers under varying site conditions. REMM was developed as a plot-scale to field-scale model to be used with upland field runoff data or in conjunction with an upland runoff model. REMM simulates a three-zone buffer system based on USDA Forest Service and USDA Natural Resources Conservation Service standards (NRCS, 1995) (fig. 6). Processes simulated in REMM include surface and subsurface hydrology; erosion, sediment transport, and deposition; C, N, phosphorous, and pesticide transport, removal, and cycling; and vegetation growth. The model operates on a daily time step. Management options such as vegetation type, buffer configuration, and biomass harvesting can be simulated.

\section{SWAT}

SWAT is a distributed, large watershed-scale hydrologic and water quality model (Arnold et al., 1998) and is a compilation of USDA-ARS efforts to model environmental processes in agricultural systems. Components of the CREAMS (daily rainfall hydrology; Knisel, 1980), GLEAMS (pesticide), and EPIC (crop growth) models are incorporated into SWAT to simulate hydrologic and sediment and nutrient cycling processes and transport. The EPIC model processes were incorporated by summarizing all processes on a limited scale to make it able to simulate large spatial and temporal scales (fig. 7). The current SWAT model is a direct descendant of the Simulator for Water Resources in Rural Basins (SWRRB) model, which simulates management impacts on water and sediment movement for ungauged rural basins across the U.S. and was a compilation of efforts by Drs. Williams and Arnold. The SWAT model's development, modifications, and support have been evolving since the early 1990s with assistance from domestic and international contributors and users. The code is public domain and has recently been using version control software. 

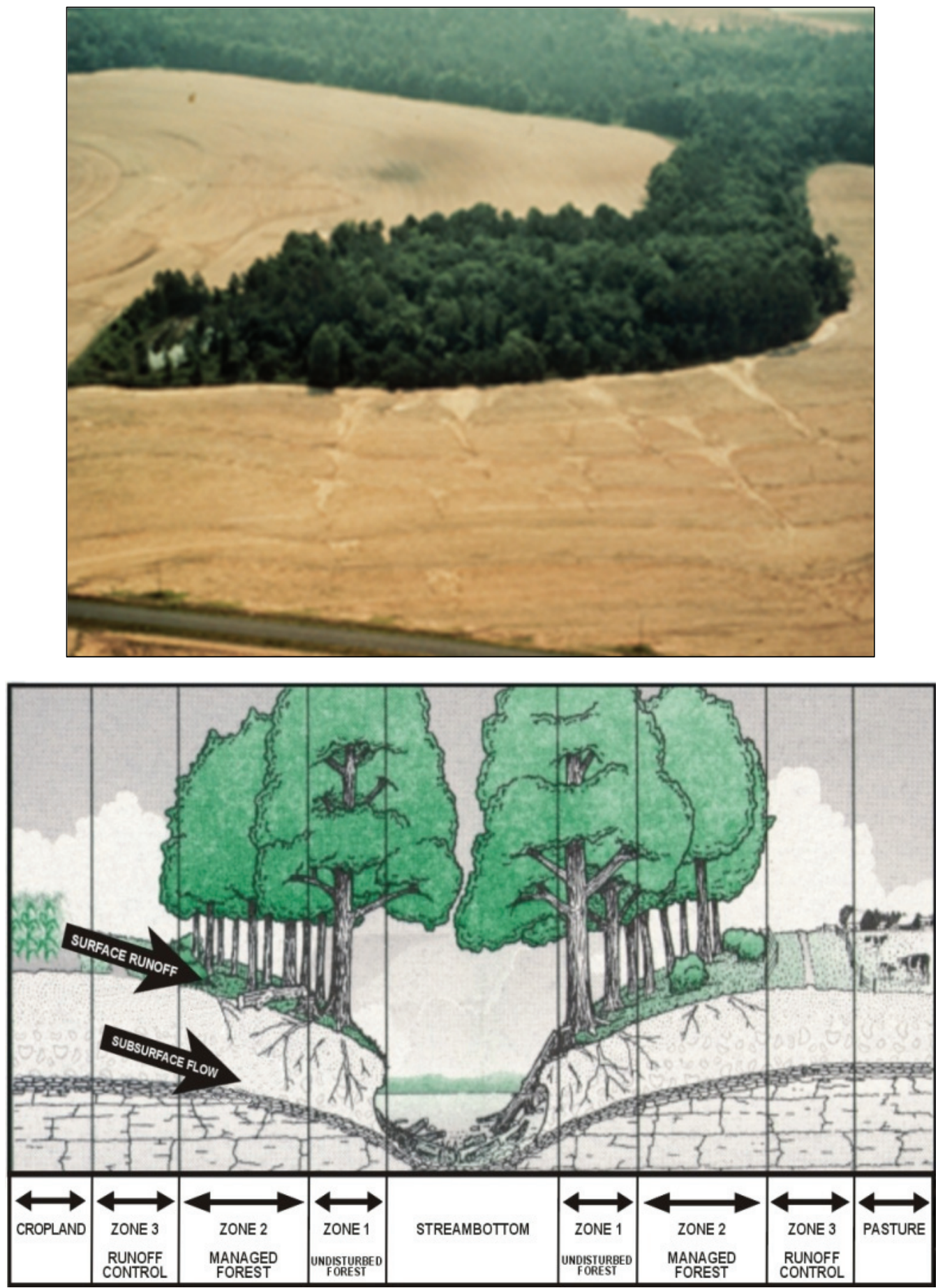

Figure 6. Aerial view of a coastal riparian buffer system (top) and a schematic of processes simulated in REMM (bottom). 


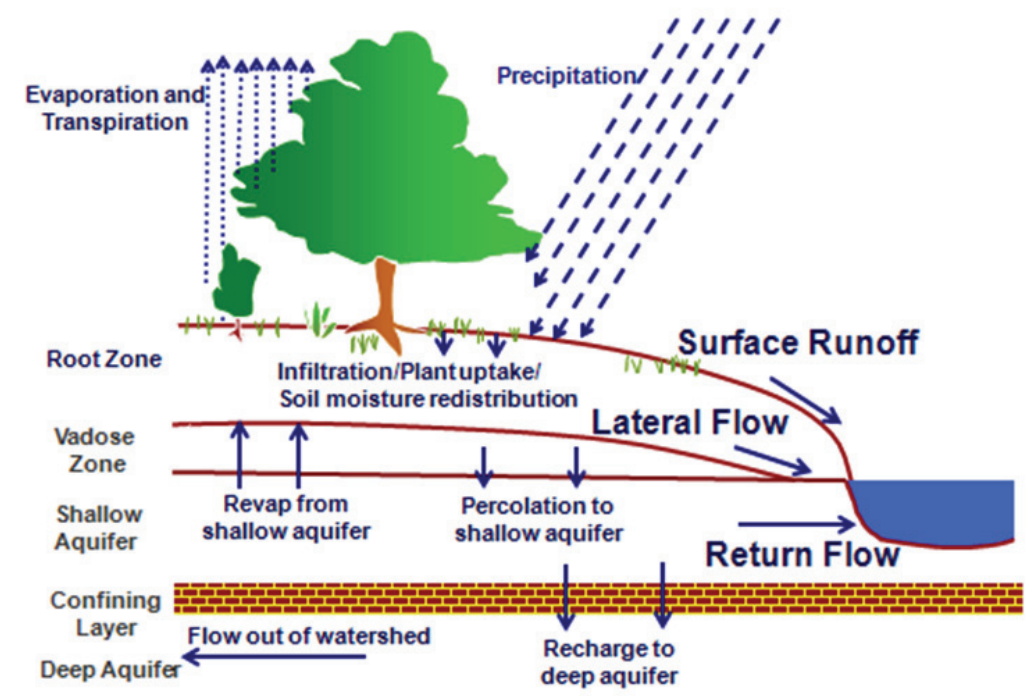

Figure 7. Schematic of hydrologic processes simulated in SWAT.

\section{Hydrologic Processes APEX}

The APEX model defaults to the CN2 approach (SCS, 1972) to generate runoff from a plot with a specific soil type classified by soil hydrologic group and land use/cover. APEX has five different options for estimating ET (table 1). A simulation area can be subdivided as much as the GIS discretizing will support (e.g., $10 \mathrm{~m}$ slope lengths). Each subarea is relatively homogeneous in terms of soil and land use, and management can reflect landscape position. The routing mechanisms provide for evaluation of interactions between subareas involving surface runoff, return flow, sediment deposition and degradation, nutrient transport, and groundwater flow (e.g., fig. 2). The applicability of APEX to forested watershed conditions was enhanced by modifying related factors such as rainfall interception by canopy, litter, subsurface flow, nutrient movement, and routing enrichment ratios (fig. 3) (Saleh et al., 2004). Subsurface flow includes vertical and horizontal components using storage routing and pipe flow equations (Williams and Izaurralde, 2005). Water table dynamics are driven by the volume of groundwater storage relative to the maximum groundwater storage. The model has components for routing water, sediment, nutrients, and pesticides across complex landscapes and channel systems to the watershed outlet (fig. 2).

APEX also has groundwater and surface reservoir components. The reservoir component simulates a water volume based on precipitation, inflows, seepage, ET, and outflows. The reservoir can have both emergency and principal spillways and lose water via drawdown. Water, sediment, and nutrients can be lost via leakage and through spillways. The APEX groundwater algorithm receives flow via the vertical or percolation component. Groundwater storage is subject to deep percolation from the water system and return flow.

\section{MIKESHE-DNDC}

This distributed watershed hydrological model simulates the detailed terrestrial water cycle, including 3-D saturated water movement in soils, 2-D water movement of overland flow, 1-D water moveent in river/streamflow, unsaturated water movement, and ET (fig. 4). ET is modeled as a function of PET, LAI, and soil moisture content using the Kristensen and Jensen (1975) method. Saturated water movement is modeled using the 3-D finite difference or linear reservoir approach. The 2-D overland flow is simulated using kinematic wave approximation. A dynamic wave version of the St. Venant equations is used to simulate 1-D water movement in river/streamflow. Unsaturated water movement is simulated using either Richard's equation or the gravity flow or two-layer water balance method (DHI, 2005). MIKESHE is a flexible watershed hydrologic modeling tool and applicable at spatial scales ranging from a single soil profile to large regions with several river catchments (Graham and Butts, 2005), and each of the hydrologic processes can be represented at different levels of spatial distribution and complexity (Butts et al., 2004). MIKESHE was coupled with the flow-routing model MIKE 11 (Sahoo et al., 2006; DHI, 2005), a 1-D river/channel water movement model to simulate flow rates in different sections of the stream channels (fig. 2). In ForestDNDC, the soil moisture regime is explicitly modeled and, thus, surface and subsurface flows are not simulated (fig. 5). Soil water content is modeled based on a simple water balance approach that uses the Thornthwaite method for ET (table 1). Linking Forest-DNDC and MIKESHE offers a powerful model to simulate both the upland and wetland hydrology and the $\mathrm{C}$ and $\mathrm{N}$ dynamics in forest and agricultural ecosystems (figs. 1 and 2).

\section{DRAINMOD-FOREST}

Key hydrological processes simulated in DRAINMODFOREST include ET, rainfall interception, surface runoff, infiltration, subsurface drainage, deep seepage, water table fluctuation, and soil water distribution (fig. 1), similar to DRAINMOD (except for ET and interception), which was originally developed as a field-scale model for drained agricultural lands (Skaggs, 1978) to assess effects of drainage system design and management on field hydrology and 
crop yield. It was extended to become a suite of models that simulate the hydrology, soil $\mathrm{C}$ and $\mathrm{N}$ dynamics, salinity, and plant growth for drained agricultural and forested lands at a field scale (Skaggs et al., 2012; Tian et al., 2012b, 2012c, 2013a; Negm, 2011; Youssef et al., 2005, 2006; Harder et al., 2006; Diggs, 2004; Amatya and Skaggs, 2001; Breve et al., 1997; Kandil et al., 1995; Chescheir et al., 1994; McCarthy et al., 1992). These are hybrid models utilizing both process-based and empirical methodologies. Several versions of DRAINMOD-based watershed-scale models have also been developed to simulate hydrology, hydraulics, and nutrient loadings associated with land use and climate change for small to medium-scale watersheds dominated by drained fields (Konyha and Skaggs, 1992; Amatya et al., 1997, 2003, 2004, 2006; Fernandez et al., 2002, 2005, 2006, 2007; Kim et al., 2012, 2013; Amoah et al., 2013).

Water balance simulations are conducted midway between two parallel drains (subsurface drain tubes or open ditches) on a section of soil, which extends from the surface down to an impermeable layer. The water balance is conducted on an hour-by-hour, day-by-day basis and can be applied to a long climatological record. The rate of subsurface drainage is computed using Hooghoudt's equation (Hooghoudt, 1940; van Schilfgaarde, 1957), which is a function of lateral hydraulic conductivity, ditch spacing and depth, depth to the impermeable layer, and water table elevation. In the case of a ponded surface, Hooghoudt's equation does not apply, and the model uses equations derived by Kirkham (1957) to predict drainage rates. Evapotranspiration in DRAINMOD is a function of daily PET calculated internally using a temperature-based Thornthwaite method or externally using Penman-Montieth or other methods with the daily PET values read in as input data. If the soil water content is greater than the lower limit dictated first by the upward flux as a function of water table and then the root zone water, ET is set equal to PET. Otherwise, ET is limited to the rate at which upward flux supplies water to the root zone. Deep seepage is computed using Darcy's equation, and infiltration is calculated using the GreenAmpt equation (Green and Ampt, 1911). A second water balance is conducted at the soil surface during rainfall events to compute surface water storage and surface drainage. When precipitation rate exceeds infiltration rates or for water tables at the surface, surface storage increases until a maximum storage value (an input to the model) is reached; any additional precipitation is allotted to surface runoff.

In contrast to the original DRAINMOD, DRAINMODFOREST internally calculates PET using the PenmanMonteith method, with canopy conductance estimated as a function of climatologically regulated stomatal conductance and leaf area index (LAI) predicted by the incorporated forest growth model. A modified version of the Gash model is used in DRAINMOD-FOREST to simulate rainfall interception for both sparse and closed canopies. However, canopy interception is calculated separately without partitioning for dry and wet canopy evaporation (fig. 1).

The DRAINMOD-based watershed-scale models delineate the watershed into multiple fields and channel segments based on the drainage ditch or canal network that connects the fields to the watershed outlet (fig. 2). The hydrology of each field is simulated by DRAINMOD, and predicted outflows are routed to a field outlet on the channel network using an instantaneous unit hydrograph modified for flatland conditions. Outflows from multiple field outlets are routed through the channel network using different methods depending on the version of the DRAINMODbased watershed-scale model. Routing methods vary from solutions to the one-dimensional, nonlinear St. Venant equations, to a simplified canal routing procedure based on methods presented by Olivera and Maidment (1999). A simple method is also available that uses travel time estimates of drainage water from specific fields to the watershed outlet. However, DRAINMOD-FOREST has not yet been incorporated into the DRAINMOD-based watershedscale model, which is an essential step to make the DRAINMOD-FOREST applicable for landscape-scale simulations.

\section{REMM}

The riparian buffer in REMM is represented as a threezone system with three soil layers in each zone (Altier et al., 2002) (fig. 6). Upland inputs to REMM provide both surface and subsurface water and $\mathrm{C}$, nutrient, and pesticide loadings. Vertical and lateral movement of water, dissolved nutrients, and pesticides are simulated on a daily time step. Surface runoff is simulated using a modified Green-Ampt process, and a mass balance approach based on field capacity is used for subsurface drainage calculation. Darcy's equation calculates the water table dynamics. The PenmanMonteith method is used to estimate ET losses (table 1). Inamdar et al. (1999a) tested the hydrologic component of the model for a coastal plain riparian buffer.

\section{SWAT}

Since SWAT is a large watershed-scale $\left(>4000 \mathrm{~km}^{2}\right)$ distributed model, the watershed is first divided into subwatersheds, each connected through a stream channel and further subdivided into hydrologic response units (HRUs) with unique combination of soils, land uses, and management practices (Borah et al., 2006). The hydrologic balance simulated per HRU includes canopy interception; partitioning of precipitation, snowmelt water, and irrigation water between surface runoff (Green-Ampt and CN2 methods) and infiltration; and redistribution of water within the soil profile, ET, lateral subsurface (kinematic storage) flow from the soil profile, and return flow from shallow aquifers (fig. 7). Groundwater is simulated via exponential baseflow recession. All processes simulated at the HRU level are on a daily time step and summarized per subwatershed. The simulated variables (water, sediment, nutrients, and pesticides) are routed through the stream network to the watershed outlet. Daily water budget is defined as change in soil water content, which is equal to precipitation and irrigation minus surface runoff, ET, percolation, and lateral (tile flow) and groundwater return (base) flow. Surface runoff is computed using the SCS (1972) runoff curve number method as well as several other algorithms from APEX. The amount reaching the stream channel is computed using an exponential function with a lag coefficient. 
Methods for estimating PET include: Penman-Monteith, Priestly-Taylor, and Hargreaves. Flows are summed from all HRUs to the subwatershed level and then routed through the stream system to the watershed outlet using a variablerate storage method or the Muskingum method (fig. 2).

\section{SoIL CARbon DYNAMICS APEX}

APEX uses the soil organic matter (SOM) model developed in EPIC to simulate the coupled cycling of $\mathrm{C}$ and $\mathrm{N}$ in soil. The SOM model in EPIC follows the approach used in the CENTURY model (Parton et al., 1987, 1988, 1993, 1994; Vitousek et al., 1994) in which there are three pools: microbial, slow, and passive. Four major differences between the CENTURY and APEX models regarding the organic transformations exist: (1) leaching equations in APEX are used to move organic materials from surface litter to subsurface layers; (2) temperature and water controls affecting transformation rates are calculated with equations currently in APEX; (3) the surface litter fraction in APEX has a slow compartment but no passive compartment; and (4) the lignin concentration in APEX is modeled as a sigmoidal function of plant age. Carbon can also be lost in gaseous form (Williams and Izaurralde, 2005). In addition to the coupling of $\mathrm{C}$ and $\mathrm{N}$ in APEX simulations, Izaurralde et al. (2012) created the capacity for $\mathrm{C}$ to be independent of $\mathrm{N}$ rather than always being proportional.

\section{MIKESHE-DNDC}

MIKESHE is a distributed watershed-scale water quantity model (fig. 4). Dai et al. (2012) linked MIKESHE with DNDC (fig. 5) to simulate spatial and temporal dynamics of greenhouse gases (GHGs), including C fluxes in soil on a watershed scale. However, the model does not simulate transport and transformation processes in the channels and streams. Forest-DNDC simulates both $\mathrm{C}$ inputs and outputs, including photosynthesis and respiration of plants, and soil heterogeneous respiration. The applied size of a watershed depends on the geography and topography. C cycling is mainly concentrated on $\mathrm{C}$ balance in the soil and vegetation, as well as GHG production and emission. The soil $\mathrm{C}$ balance is calculated as in equation 1 :

$$
\begin{aligned}
\text { SOC } & =\text { litter } \mathrm{C}+\text { fertilizer } \mathrm{C}-\text { leaching } \mathrm{C} \\
& - \text { soil-respired } \mathrm{C}
\end{aligned}
$$

\section{DRAINMOD-FOREST}

DRAINMOD-FOREST simulates soil $\mathrm{C}$ and $\mathrm{N}$ cycling using the methods provided in DRAINMOD-N II (fig. 1). Organic $\mathrm{C}$ dynamics are simulated using a process-based $\mathrm{C}$-cycling method similar to that of the CENTURY model (Parton et al., 1993). The organic C (OC) is divided into three soil pools (active, slow, and passive), two aboveground and below-ground residue pools (metabolic and structural), and a surface microbial pool. The model simulates OC decomposition using first-order rate kinetics and reduces potential decomposition rates for different pools in response to non-optimum soil temperature and water conditions. The temperature constraint function is based on a form of the Van't Hoff equation with variable Q10. The water stress constraint is a function of a user-defined soil moisture range, under which the optimum biological processes can be reached. DRAINMOD-N II was slightly modified to account for the effects of site preparation (chopping, shearing, bedding, etc.) on soil $\mathrm{C}$ cycling in forest ecosystems. In DRAINMOD-FOREST, continuous litter fall of foliage, root turnover, and slashes produced from silvicultural practices such as thinning, harvesting, and pruning are direct organic $\mathrm{C}$ sources for soil $\mathrm{C}$ cycling.

\section{REMM}

REMM's soil $\mathrm{C}$ dynamics are mainly based on the CENTURY model (Parton et al., 1987, 1988). Soil C is characterized by two plant residue pools and three humus pools. The three pools are active biomass and metabolites of biomass with a rapid decay rate, slower-decaying organic matter that has been partially chemically or physically stabilized or entrapped with soil aggregates, and passive chemically stabilized organic matter with a very slow decay rate. Decomposition of the pools is a function of moisture and temperature and is calculated using a first-order rate equation. The plant residue pools are divided into a structural pool and a quickly decomposable metabolic residue pool. Like the humus pools, these pools have different decay rates and $\mathrm{C}: \mathrm{N}$ ratios. Fresh residue is added to the pools on a daily time step. Carbon movement is simulated in dissolved surface, subsurface, and drainage flows and in particulate form with sediment. The $\mathrm{C}$ moving with the sediment is derived from the active humus pool, and the dissolved $\mathrm{C}$ is assumed to derive from the metabolic and active humus pools. Drainage from soil layers, lateral movement between zones, and surface runoff are calculated on a daily time step.

\section{SWAT}

SWAT currently assumes that soil $\mathrm{C}$ contents are static. A second option for soil $\mathrm{C}$ dynamics including $\mathrm{C}$ fractionation, tillage operation impact, and root decomposition is currently being adapted from the one $\mathrm{C}$ pool methodology presented by Kemanian and Stöckle (2010) and Kemanian et al. (2011). The soil C decomposition follows first-order kinetics based on the Hénin and Dupuis (1945) equation (eq. 2):

$$
\frac{d \mathrm{C}_{S}}{d t}=h \mathrm{C}_{i}-k \mathrm{C}_{s}
$$

where $\mathrm{C}_{s}$ is the soil organic $\mathrm{C}\left(\mathrm{Mg} \mathrm{ha}^{-1}\right), t$ is the time (year), $h$ is the humification constant, $\mathrm{C}_{i}$ is the $\mathrm{C}$ input, and $k$ is the apparent soil turnover rate. This approach has minimal input requirements and can accommodate multiple management scenarios. The adaptation also considers soil texture, root and aboveground biomass, soil $\mathrm{C}$ saturation, and soil temperature and moisture factors. 


\section{Nitrogen DyNAMics APEX}

Soil $\mathrm{N}$ cycling is coupled to $\mathrm{C}$ cycling and therefore follows the same three compartments as C (microbial, slow, and passive). Actual $\mathrm{C}$ and $\mathrm{N}$ transformations are calculated based on the $\mathrm{N}$ supply available from each potential transformation (e.g., fig. 1). The demand for $\mathrm{N}$ is established by the potential $\mathrm{C}$ transformation of the source compartment and the C:N ratio of the receiving compartment. The C:N ratios of the receiving compartments vary with substrate and soil conditions (Parton et al., 1993; Vitousek et al., 1994). Nitrogen can be leached or lost in gaseous forms. Nitrification is based on the first-order kinetic equation of Reddy et al. (1979), which reflects nitrification, volatilization (includes wind speed), soil water content, and $\mathrm{pH}$. Nitrogen present in rainfall can be added to soil concentrations.

\section{MIKESHE-DNDC}

In the MIKESHE-DNDC linked model (Dai et al., 2012), Forest-DNDC considers most N processes in the forest ecosystem, including plant uptake, fixation, wet and dry deposition, chemical and organic fertilization, volatilization, mineralization, $\mathrm{N}$ loss to trace gas emissions during nitrification and denitrification, and leaching ( $\mathrm{Li}$ et al., 2000) (fig. 1). N cycling is mainly concentrated on $\mathrm{N}$ balance in the soil and vegetation, as well as GHG production and emission. Soil $\mathrm{N}$ balance is calculated by equation 3 :

$$
\begin{aligned}
\mathrm{SN} & =\text { litter } \mathrm{N}+\text { fertilizer } \mathrm{N}+\text { precipitation } \mathrm{N} \\
& - \text { plant uptake } \mathrm{N}-\text { leaching } \mathrm{N}-\mathrm{N}(\mathrm{g})
\end{aligned}
$$

\section{DRAINMOD-FOREST}

In DRAINMOD-FOREST, detailed $\mathrm{N}$ cycling is simulated based on DRAINMOD-N II, which considers both mineral $\mathrm{N}\left(\mathrm{NO}_{3}-\mathrm{N}, \mathrm{NH}_{4}-\mathrm{N}\right.$, and $\left.\mathrm{NH}_{3}-\mathrm{N}\right)$ and organic $\mathrm{N}$ and their interactions as affected by $\mathrm{C}$ cycling. The model simulates atmospheric deposition, plant uptake, $\mathrm{N}$ fixation by legumes, $\mathrm{N}$ mineralization and immobilization, nitrification, denitrification, $\mathrm{NH}_{3}$ volatilization, and mineral $\mathrm{N}$ losses via subsurface drainage and surface runoff. It simulates farming practices such as tillage and plant residue management and the application of mineral $\mathrm{N}$ fertilizers and animal manure (fig. 1).

The model simulates $\mathrm{N}$ transport using numerical solution to a multiphase form of the one-dimensional advection-dispersion-reaction equation. The nitrification and denitrification processes are simulated using a MichaelisMenten function with environmental constraints similar to functions used for regulating soil $\mathrm{C}$ cycling. Recently, the DRAINMOD-N II model was modified to simulate DON from drained agricultural and forest ecosystems and was incorporated into DRAINMOD-FOREST to simulate the long-term DON export dynamics from several loblolly pine plantations (Tian et al., 2013a). In-stream processes are characterized by a first-order decay equation (eq. 4) in the water quality submodel of the watershed-scale model DRAINMOD-W (Fernandez et al., 2005):

$$
\frac{d \mathrm{C}}{d t}=-k \mathrm{C}
$$

where coefficient $k=\rho / d$, where $\rho$ is the mass transfer coefficient, and $d$ is the depth of water (Birgand et al., 2007). DRAINMOD-DUFLOW (Fernandez et al., 2005), DRAINMOD-GIS (Fernandez et al., 2006), and WATGIS (Fernandez et al., 2002) also use the same method without the mass transfer coefficient, although other in-stream process methods can be used in DUFLOW (Fernandez et al., 2005). DRAINWAT-predicted daily average stream velocities can be used in the first-order decay rate equation for $\mathrm{N}$ transformation to predict field $\mathrm{N}$ export, or field exports either from the literature or predicted by other field-scale models can be used (Amatya et al., 2004).

\section{REMM}

In REMM, organic $\mathrm{N}$ pools mirror organic $\mathrm{C}$ pools, with the size of the $\mathrm{N}$ pool being determined by their respective $\mathrm{C}: \mathrm{N}$ ratios. Stoichiometric relationships are assumed between $\mathrm{C}$ and $\mathrm{N}$, with mineralization and immobilization proportional to transformations of $\mathrm{C}$ and $\mathrm{C}: \mathrm{N}$ ratios. Mineralized $\mathrm{N}$ is added to the ammonium pool. Immobilization of nitrate occurs only after all of the available ammonium has been immobilized. Ammonium nitrification in REMM follows the approach of Reuss and Innis (1977) and Godwin and Jones (1991), which is based on a Michaelis-Menten function described by McLaren (1970). It is a temperature, moisture, and $\mathrm{pH}$ influenced first-order rate equation. Nitrate denitrification is calculated as a function of the available nitrate- $\mathrm{N}$, available $\mathrm{C}$, moisture, and temperature (Inamdar et al., 1999b).

Nitrogen movement occurs with sediment, surface and subsurface runoff, and vertical drainage. It is assumed that ammonium and active organic $\mathrm{N}$ are transported with sediment and that nitrate, dissolved ammonium, and dissolved organic $\mathrm{N}$ move with runoff and drainage (Inamdar et al., 1999b). A Freundlich isotherm approach, as presented by Preul and Schroepfer (1968), is used to calculate adsorption and desorption of ammonium between water and soil particles.

\section{SWAT}

SWAT can estimate HRU-level N concentrations, which are summed at the subwatershed level. The losses are routed through channels, ponds, wetlands, depressional areas, and/or reservoirs to the watershed outlet. SWAT has the option to select the routing of in-stream nutrient loadings with transformations (QUAL2E transport model) or without transformations. Nitrogen cycling is coupled to soil organic $\mathrm{C}$ cycling dynamics. SWAT monitors five pools of soil $\mathrm{N}$ (mineral: $\mathrm{NH}_{4}{ }^{+}, \mathrm{NO}_{3}{ }^{-}$; organic: active, stable, and fresh) (fig. 1). The user can specify initial $\mathrm{N}$ levels, or the model can initialize the levels itself. Initial nutrient levels can be input as concentrations; however, all calculations are performed on a mass basis. Rainfall-related N concentrations are added to soil $\mathrm{N}$ levels when present. Nitrogen can be fixed and move upward through the soil profile depending on the soil water content. The SWAT model extended for detailed $\mathrm{N}$ turnover and cycling with modules borrowed 
from DNDC (SWAT-N) can simulate decomposition, growth of nitrifying bacteria, nitrification, nitrificatory and denitrificatory $\mathrm{N}$ emissions, $\mathrm{N}$ uptake by plants, and $\mathrm{N}$ transport due to $\mathrm{N}$ fluxes (Pohlert at al., 2007).

\section{Nitrogen AND CARBON TRANSFORMATIONS IN RESPONSE TO SOIL MOISTURE}

The five models are not very different in their approach to simulating $\mathrm{N}$ and $\mathrm{C}$ transformation processes related to soil moisture. The transformation of $\mathrm{N}$ is followed by reattainment of equilibrium through a shifting of the labile, active, and passive pools. However, the initial amount of $\mathrm{N}$ available plays a pertinent role. Nitrogen comes from different sources; but the key process is when $\mathrm{N}$ is released from organic matter decomposition (OMD) because $\mathrm{N}$ from other resources is more readily available. When a decomposition routine is inadequate, the remaining $\mathrm{N}$ processes may be misleading or incorrect. Carbon models can also have this problem. Carbon models that focus mostly on biomass use a simple soil routine (e.g., SWAT; Kemanian et al., 2011) or a single soil layer with the average of soil conditions in a soil profile and do not divide the soil into different layers. In the real world, the difference in equilibrium conditions among the soil layers is large for thick soils and wetland soils. Most of the simple C models cannot perform well for $\mathrm{N}$ transformation.

DNDC uses a multi-layer soil model with each layer $<3 \mathrm{~cm}$ in thickness to quantify the $\mathrm{C}$ and $\mathrm{N}$ dynamics in soils. The microbial activity, including decomposer, nitrifier, and denitrifier, is modeled hourly in each soil layer, followed by modeling hourly hydrothermal balance, redox, and gaseous diffusion (Li et al., 1992, 2000; Li, 2007). Organic matter is divided into three components, e.g., easy, medium and slow to decompose. The decomposition rate of each component per soil layer depends on the decomposition activity per soil layer. Accordingly, the OMD rate can be different from layer to layer at any time point. Similarly, $\mathrm{N}$ transformation is dependent on the activities of the nitrifier and denitrifier and the equilibriums in each soil layer based on the hydrothermal balance, redox, gaseous diffusion, and available $\mathrm{N}$ coming from the OMD and additions related to transportation and fertilization.

APEX uses a modified CENTURY model (Parton et al., 1987, 1993, 1994) approach to simulate $\mathrm{C}$ and $\mathrm{N}$ cycling and transformations and also uses a multi-soil layer approach in which the user specifies the depth of each layer. Soil moisture and temperature control the microbial processes. For example, with increased moisture and temperature, soil organic matter can be split into active, slow, and passive pools. However, if there is a limited amount of organics to mineralize, then soil moisture and temperature will have a more nominal impact. Temperature and water controls in APEX affecting transformation rates are calculated concurrently. In addition, the surface litter fraction has an active and a slow pool but lacks a passive pool. Potential transformations are based on substrate-specific rate constants, temperature, and water content. The transformations are considered potential because completion is when sufficient quantities of organic and inorganic $\mathrm{N}$ are available (Williams and Izaurralde, 2005).
The SWAT model uses a more simplistic $\mathrm{C}$ version than the APEX model. Temperature and soil moisture still impact the rate of microbial processes (e.g., increased temperature and moisture results in greater mineralization rates, and vice versa), but it contains two options: a static pool or a one-pool method (Kemanian and Stöckle, 2010) since this model was built to capture very large spatial-scale simulations. Traditionally, APEX outputs would be used as inputs to the SWAT model to capture the details necessary for $\mathrm{C}$ and $\mathrm{N}$ transformations as related to soil moisture regimes. Nitrogen is represented by the same three pools present in APEX.

In DRAINMOD-FOREST, the soil $\mathrm{C}$ and $\mathrm{N}$ model simulates organic $\mathrm{C}$ (OC) dynamics using a process-based $\mathrm{C}$ cycling method similar to the CENTURY model (Parton et al., 1993) in APEX. The OC is divided into three soil pools (active, slow, and passive), two above-ground and belowground residue pools (metabolic and structural), and a surface microbial pool. The model simulates OC decomposition using first-order rate kinetics and reduces the potential decomposition rates for non-optimum soil temperature and moisture conditions. The soil moisture control on soil $\mathrm{C}$ and $\mathrm{N}$ cycling is quantified by a constraint function that results in a factor ranging from 0 to 1 , with 0 meaning that the process is totally inhibited and 1 suggesting no moisture limits. The constraint function for most soil $\mathrm{C} / \mathrm{N}$-related processes simulated in DRAINMOD-FOREST is characterized by the upper and lower limits of the relative saturation, between which the optimum rates can be achieved, while the process rate decreases beyond these limits. DRAINMOD-FOREST simulates soil moisture effects on denitrification using a function that assumes that denitrification proceeds at optimum once the soil is saturated. The denitrification rate decreases exponentially until a user-defined relative saturation threshold, below which denitrification ceases.

REMM uses a water factor (WFac), which is a 0 to 1 scalar to adjust $\mathrm{C}$ residue and humus release based on water-filled pore space (Linn and Doran, 1984). The same water factor used for $\mathrm{C}$ is used to determine nitrification. Denitrification has an anaerobic factor that includes a water factor based on water-filled pore space. This is a different equation than the $\mathrm{C}$ water factor, but it is also a 0 to $1 \mathrm{sca}-$ lar. Although temperature and moisture may be favorable for $\mathrm{C}$ mineralization, the rate of decomposition is also influenced by the composition of the residue (Gorissen et al., 1995). The C:N:P factors for metabolic and structural residue are based on Parton et al. (1987). The amount of readily decomposable $\mathrm{C}$ augments the effect of moisture on denitrification.

\section{VEGETATION GROWTH APEX AND SWAT}

The APEX model's plant growth and plant competition modules are independent of the ALMANAC model, whereas the SWAT model's plant growth and competition have been enhanced to link to the ALMANAC model (Kiniry et al., 1992). All of the options available in ALMANAC are 
available in APEX, including canopy cover, plant competition, and several plant physiological parameters, as well as many others. The plant species available in ALMANAC are available in APEX, and APEX's crop.dat file can be readily altered to reflect location-specific plant characteristics. At the time of writing, SWAT has been altered to simulate individual tree growth. Recent changes to ALMANAC allow for the growth of mixed plant and tree stands. MacDonald et al. (2008) and Kiniry et al. (2008) present adaptations made to include successional changes in forest ecosystems and successional processes of different forestry mixtures, including disturbances and competition for light, nutrients, and water. ALMANAC simulates LAI, includes light interception with Beer's law, and simulates potential daily biomass increase with a species-specific value of RUE. Light intercepted by each species is a function of its extinction coefficient, its contribution to total leaf area, and its current height. Landscape units of forested watersheds are delineated as "forest stands" that consist of distinct areas of forest of a single or consistent combination of tree species of similar age and productivity.

\section{MIKESHE-DNDC}

There is no vegetation growth module in MIKESHE, but the recently linked MIKESHE-DNDC simulates forest productivity for above-ground and below-ground biomass through Forest-DNDC. Forest-DNDC is based on the PnET-DNDC model; thus, vegetation growth in ForestDNDC is similar to PnET (Aber and Federer, 1992). Plant growth in DNDC is based on water and nutrition availability (eq. 5):

$$
B=f(e, W, N, t)
$$

where $B$ is biomass, $e$ is energy, $W$ is soil moisture, $N$ is nutrition, and $t$ is time. If water or nutrition is limiting, plant growth will slow or stop, and mortality can occur. While water is the factor most often limiting growth, solar radiation (light) is also important. Vegetation is divided into overstory, understory, and ground, with growth parameters specific to each. The soil organic $\mathrm{C}$ and $\mathrm{N}$ pools are dynamic in this model, and the pools vary with organic matter accumulation, consumption, and decomposition and litter decomposition and deposition.

\section{DRAINMOD-FOREST}

The tree growth and forest productivity component divides the forest canopy into overstory, mid-story, and understory depending on the tree height and stocking number (fig. 1). The RUE method is used to estimate the gross primary production of the forest ecosystem as a function of intercepted photosynthetic radiation, which is also constrained by environmental factors and soil conditions. Net primary production can be estimated as a constant fraction of the gross primary productivity (GPP) or determined as the difference between the GPP and plant respiration. Assimilated $\mathrm{C}$ is partitioned into various tree components including foliage, stem, and root using tree species-dependent allometric relationships and is also regulated by tree age, soil water, and $\mathrm{N}$ conditions. Carbon losses through litterfall are estimated as a function of leaf longevity, while root turnover is quantified using a species-specific fine root lifespan. Fertilizer application is simulated using the fertilizer component of DRAINMOD-N II, which simulates the short-term processes of fertilizer dissolution, urea hydrolysis, and soil $\mathrm{pH}$ changes following fertilizer application. The model simulates effects of environmental factors and $\mathrm{N}$ availability on tree growth. The model can simulate mixed species or uneven age stands, and growth of both evergreen and deciduous trees.

\section{REMM}

Vegetation growth in REMM is simulated on a stand basis. Vegetation growth is in the upper and lower canopy, and up to six plant types can be represented in each canopy. Plant types consist of evergreen and deciduous woody species and annual and perennial herbaceous species (Lowrance et al., 2000; Altier et al., 2002). Vegetation growth processes in REMM are simulated using algorithms derived from mechanistic models including TREGRO (Weinstein et al., 1992), FOREST-BGC (Running and Coughlan, 1988; Running and Gower, 1991), and SUCROSE (van Kuelen et al., 1982). REMM vegetation influences soil nutrients either from litter fall or plant uptake. $\mathrm{N}$ and $\mathrm{P}$ are released by decomposition from the aboveground plant parts (leaves, stems, and branches) to a surface litter layer. Below-ground plant parts (coarse and fine roots) are added to soil residue pools, where they are subject to decomposition (Inamdar et al., 1999b). Nutrient uptake by plants is determined by the lesser of plant demand or nutrient availability. Plant demand is a dynamic function needed to maintain nutrients in various plant parts within predefined $\mathrm{C}: \mathrm{N}$ and $\mathrm{C}: \mathrm{P}$ ratios. In the soil, nitrate-N, ammonium-N, and labile-P are available for uptake when the soil moisture is above wilting point.

\section{MODEL INPUTS AND VARIABLES APEX AND SWAT}

APEX and SWAT both provide considerable flexibility in input requirements. These models are capable of estimating several inputs that may not be readily available. Both models have multiple GIS interfaces available. Base model inputs include soil physical and hydraulic input parameters (bulk density, soil depth, CN2, field capacity, etc.; Neitsch et al., 2005) and land use data (tillage practices, pesticide and fertilizer applications, irrigation, tile drains, potholes, and urban characteristics). The inclusion of sediment partitioned into five particle size classes is currently being tested. The climatic inputs include total precipitation, maximum and minimum air temperature, total solar radiation, average relative humidity, and wind speed. Values for all these parameters may be read from records of observed data, or they may be generated. Weather parameters are used to estimate daily PET (table 1). Vegetation growth relies on plant growth database parameters (RUE, LAI, potential heat units, canopy height, $\mathrm{N}$ and $\mathrm{P}$ uptake parameters, stomatal conductance, and USLE C factor) included for common plant species; additional species can be included as well. Nutrient-related parameters include $\mathrm{C}: \mathrm{N}$ ratio, $\mathrm{N}$ 
and $\mathrm{P}$ enrichment ratios, organic $\mathrm{C}$ content, etc. Flow routing in canals and streams requires hydraulic parameters such as average slope length and steepness, cross-sectional area, Manning's n, bed slope, and lateral flow travel time (table 1). APEX offers two options for routing water through channels and floodplains: a daily time step average flow method, and a short time interval complete flood routing method.

\section{MIKESHE-DNDC}

Input parameters for the MIKESHE-DNDC climate module include daily rainfall and PET, estimated externally using air temperature, wind speed, relative humidity, solar radiation, and vapor pressure. Topographical data such as DEMs are essential. Soil physical properties such as lateral and vertical hydraulic conductivity of each layer, bulk density, field capacity, wilting point, specific yield, porosity, etc., are required. The dynamics (daily or other time interval) of LAI is an important input in the model. Input parameters for saturated and unsaturated zones and overland flow are also required (table 1). Other parameters for flow include the channel or stream network and hydraulic characteristics such as Manning roughness, slopes, widths, and depths. Other soil input parameters include physical and chemical properties such as depth of the layer, bulk density, porosity, field capacity, wilting point, $\mathrm{C}$ content, $\mathrm{pH}$, fraction of organic matter (OM), $\mathrm{C}: \mathrm{N}$ ratio in $\mathrm{OM}$, and particle size distribution (table 1). Plant physiological and phenological parameters include overstory, understory, and ground, including current biomass in different parts of plants, $\mathrm{N}$ content, and plant growth parameters (a total of 53 vegetation parameters, with $53 \times 2=106$ values for one simulation unit). $\mathrm{N}$ deposition in the precipitation is also an input. Further details are provided by Dai et al. (2012) and Li et al. (2000).

\section{DRAINMOD-FOREST}

The DRAINMOD-FOREST model requires three types of inputs: climatic and hydrologic, soil $\mathrm{C}$ and $\mathrm{N}$, and vegetation. Climatic parameters include hourly precipitation and daily maximum and minimum air temperatures for the Thornthwaite-based PET estimate (table 1). A full climatic record including air temperature, humidity, wind speed, and radiation is currently required by the model in order to calculate PET using the Penman-Monteith method, although some of these climatic variables can be empirically derived. The main hydrologic inputs are drain depth and spacing, surface depressional storage, depth to the impervious layer, and soil hydraulic properties for each soil layer, including lateral saturated hydraulic conductivity and soil water retention relationships. Soil $\mathrm{C}$ and $\mathrm{N}$ inputs include soil physical and chemical properties and rate coefficients for biological processes regulating $\mathrm{N}$ transformations and organic C decomposition. Several important vegetation inputs are required, including quantum use efficiency, $\mathrm{C}$ use efficiency, light extinction coefficient, maximum stomatal conductance, $\mathrm{C}$ allocation coefficients, specific leaf area, and leaf longevity.

The DRAINMOD-based watershed-scale models require additional in-stream input parameters for channel hydraulics such as channel dimensions, bed slope, Manning's n, length, and channel configuration (table 1). First-order decay parameters are needed for the lumped in-stream transport and transformation models (Amatya et al., 2004; Fernandez et al., 2002, 2007), but a large number of instream parameters may be needed when using full mechanistic methods (Fernandez et al., 2005, 2006).

\section{REMM}

REMM requires soil, vegetation, and land use inputs to parameterize the model, as well as daily weather and upland runoff characteristics. The inputs required to parameterize REMM are divided into those that define the buffer and the vegetation type. Buffer inputs for each zone include length, width, depth of the soil horizons, and surface Manning's n. Inputs for each soil horizon include saturated hydraulic conductivity, soil moisture characteristics, soil texture and initial $\mathrm{C}, \mathrm{N}$, and $\mathrm{P}$ pools. REMM's vegetation input data include specific leaf area, maximum LAI, light extinction coefficient, relative growth and death rates, lignin to $\mathrm{N}$ ratios, and starting vegetation $\mathrm{C}, \mathrm{N}$, and $\mathrm{P}$ pools. Daily weather inputs of precipitation, precipitation duration, maximum and minimum temperatures, solar radiation, wind speed, and dew point temperatures are required for estimating PET (table 1). Daily upland runoff inputs of surface and subsurface runoff depth, sediment load and size distribution, $\mathrm{C}$ and nutrient concentrations for the surface and subsurface flows, and $\mathrm{C}, \mathrm{N}$, and $\mathrm{P}$ in precipitation are also required.

\section{SWAT}

All the above-mentioned APEX model input parameters and variables apply to SWAT with a few exceptions. In addition, basic spatial input data characterizing the watershed and its delineation for boundaries and subwatersheds required by the model are: topography or digital elevation models (DEMs), hydrography, soils, and land use/cover. SWAT's HRU definition automatically computes the $\mathrm{CN}$ for each HRU, which is untrackable in time and space. There are several other parameters for surface and shallow groundwater generation processes, as described in the SWAT manual (Neitsch et al., 2005). SWAT uses Manning's equation to define the rate and velocity of flow. Flows are summed from all HRUs to the subwatershed level and then routed through the stream system using either the variable-rate storage method (Williams, 1969) or the Muskingum method (Neitsch et al., 2005), which are both variations of the kinematic wave approach.

\section{MODEl OUTPUTS APEX AND SWAT}

A difference between APEX and SWAT output is that APEX contains an economic component comprised of a crop budget and accounting subsystem that keeps track of the costs of producing and marketing the crops. Both models can print output files on daily, monthly, or yearly time steps. The output summary file provides farm-level and 
watershed-level average loadings to the streams, which are also available at the subbasin/subarea and channel reach levels. Model simulation outputs are obtained for hydrology (precipitation, ET, PET, irrigation, snowfall, snowmelt, surface runoff, subsurface flow, total water yield/streamflow), sediment yield, organic and mineral forms of $\mathrm{N}$ and $\mathrm{P}$, pesticides, herbicides, $\mathrm{N}$ and $\mathrm{P}$ fertilizers applied, salinity (APEX), and bacteria (SWAT).

\section{MIKESHE-DNDC}

The hydrologic output variables of this linked model are surface runoff, base (groundwater) flow, total discharge (streamflow), canopy interception, ET, and water table depths on a daily basis or finer scales from MIKESHE. Spatial distribution of any of these variables is available as streamflow rates at selected points in the stream network. DNDC model outputs are dependent on the user's choice during the model setup of daily or yearly results. Outputs for vegetation include photosynthesis, respiration, and $\mathrm{C}$ and $\mathrm{N}$ in leaves, wood, and roots. Vegetation is divided into three layers, with each layer having its own outputs. Outputs for soil are $\mathrm{C}$ and $\mathrm{N}$ in the forest floor, mineral soil, and different SOM fractions. Other outputs include $\mathrm{N}$ mineralization and volatilization, $\mathrm{C}$ and $\mathrm{N}$ leaching, and emissions of gases such as $\mathrm{NO}, \mathrm{N}_{2} \mathrm{O}, \mathrm{N}_{2}, \mathrm{NH}_{3}, \mathrm{CH}_{4}$, and $\mathrm{CO}_{2}$. Hydrologic and climatic outputs include precipitation, ET, air temperature, and soil temperature and moisture.

\section{DRAINMOD-FOREST}

Standard hydrologic outputs include surface runoff, subsurface drainage, total water loss, ET, and water table depth on daily, monthly, and annual time steps. DRAINMODFOREST predicts LAI, canopy interception, throughfall, net rainfall, transpiration, and ET. Nitrogen outputs include daily concentrations of mineral $\mathrm{N}$ (e.g., $\mathrm{NO}_{3}$ and $\mathrm{NH}_{4}$ ) in soil solution and drain flow, soil organic $\mathrm{C}$ to a depth of 20 $\mathrm{cm}$, and microbial $\mathrm{N}$ processes on a daily, monthly, and annual basis. With the modified DRAINMOD-N II model, DRAINMOD-FOREST can also predict DON losses from forest ecosystems (Tian et al., 2013a). Additional outputs at the watershed scale are daily, monthly, and annual outflows and $\mathrm{N}$ loads at field and watershed outlets. Outputs also include monthly and annual delivery ratios (the ratio of the $\mathrm{N}$ load delivered to the outlet divided by the load at the field edge) for each field in the watershed.

\section{REMM}

Model outputs include estimates of inflow and outflow from each simulated zone (fig. 6). Outputs include sediment, surface and subsurface water depths, and C, N, and P associated with water and sediments. Zones include sediment, surface and subsurface water depths, and C, N, and P associated with water and sediments. State variable outputs include water table depth, groundwater $\mathrm{N}$ and $\mathrm{P}$ concentrations, and pool concentrations of $\mathrm{C}, \mathrm{N}$, and $\mathrm{P}$ as described above under $\mathrm{N}$ cycling. Vegetation outputs include $\mathrm{C}, \mathrm{N}$, and $\mathrm{P}$ associated with leaves, stems, branches, and fine and coarse roots. Outputs are reported on a daily, monthly, and annual basis.

\section{Management Practices APEX}

Recent work has focused on adaptation of APEX to forest conditions. APEX has multiple options to calculate sediment loadings, including RUSLE2, USLE, and variations of MUSLE. Sediment loading is independent of source (e.g., agricultural or forestry). APEX has the capability to directly route water and its contents from one subwatershed to another based on user knowledge. Forestry management practices include, but are not limited to, bulldozing, clearcutting, tree thinning, roads, drainage ditches, and pesticide applications. Both soil and foliage deterioration can occur. To date, the predictive capabilities of APEX have been validated using data from the Alto watershed and the Dry Creek watershed. Saleh et al. (2004) concluded that the modified version of APEX was able to reasonably simulate water quality and quantity from a variety of forest stand conditions and site preparation treatments by testing this model on nine small watersheds in Alto, Texas. Saleh et al. (2006) and Wang et al. (2007) applied the same model to nine small and four larger watersheds with newer data sets in the Alto area and made the same conclusions as Saleh et al. (2004). Additional refinement and validation of APEX is needed to improve model capability to appreciate SMZ contributions to water quality maintenance at the stand and watershed-scales.

\section{MIKESHE-DNDC}

MIKESHE contains only some water management functions to control streamflow, channel water levels, and water table depths, including pumping, diversion, and dams or reservoirs. Forest management practices for pine and hardwoods are addressed using the field-scale forest version of DNDC and include harvesting, chopping, burning, draining (wetlands), fertilization, and planting (Li et al., 2004a). Impacts of long-term forest management, climatic variability, and a natural disturbance (Hurricane Hugo) on streamflow, water table, and $\mathrm{N}$ cycling on forested wetlands in the coastal plain using MIKESHE-DNDC have been reported elsewhere (Dai et al., 2012, 2013).

\section{DRAINMOD-FOREST}

DRAINMOD-FOREST is a newly developed standlevel forest ecosystem model whose three core components (DRAINMOD, DRAINMOD-N II, and 3-PG) have been widely used. DRAINMOD (Skaggs, 1978; Skaggs et al., 2012) is well documented and has been applied to reliably predict water table fluctuations and outflow for a range of soil types, cropping systems, and water table management practices, including controlled drainage and subirrigation (Skaggs et al., 1981; Skaggs, 1982; Fouss et al., 1987). The soil C and N model DRAINMOD-N II has been successfully tested using field data from artificially drained soils with contrasting soil types, climatic conditions, and farming practices (Youssef et al., 2006; Bechtold et al., 2007; Thorp et al., 2009). Similarly, DRAINMOD-FOREST has recently been successfully tested for various water management and silvicultural treatments (harvesting, thinning, regeneration, and fertilization) on pine plantation sites in North 
Carolina (Tian et al., 2012c). The watershed-scale versions of the models do not yet consider management practices in the stream network, except for weirs and dams.

\section{REMM}

Management options such as vegetation type, buffer configuration, biomass harvesting, thinning, and burning are simulated. REMM has been applied to evaluate hydrologic and water quality impacts of riparian buffers using the USDA experimental buffer systems in the coastal plain. Good agreement between simulated and observed data has been obtained for water table depths and groundwater $\mathrm{NO}_{3}$ concentrations in a mature riparian forest buffer (Lowrance et al., 2000). Results showed that a combined forest and grass buffer is effective in reducing stream nutrient concentrations (Lowrance and Sheridan, 2005). REMM has been used to help characterize the role of a buffer system on stream water quality (Bhat et al., 2007). Recent work with the model has focused on application for optimizing buffer sizes based on potential nutrient loading.

\section{SWAT}

SWAT has been widely used nationally and internationally due to its ability to be applied on ungauged basins (Neitsch et al., 2005) as well as for a myriad of applications ranging from general hydrologic assessments, impacts of agricultural management practices, irrigation and groundwater withdrawal, reservoirs, impoundments, land use change, and climate change. Details of such applications have been reviewed by Gassman et al. (2007) and DouglasMankin et al. (2010). The hydrology and crop files, weather, management practices, soil files, pesticides, $\mathrm{CN}$, and some nutrient pools are adapted from APEX, but water quantity and quality results are summed at the subbasin level and the watershed outlet.

\section{ERROR AND UNCERTAINTY ANALYSIS}

Forest managers need clear and reliable assessments, to a certain degree of certainty, of the fate of fertilizer applied to southern pine plantations, which carry risks with respect to land use objectives and ecological impacts (Amatya et al., 2003). A statistical uncertainty analysis of forest fertilizer fate allows such risks to be quantified in terms of possible errors (probability distributions) associated with management decisions. This approach also helps bridge the gap between the complexities of measuring and modeling fertilizer fate and the needs of managers and policymakers to maximize fertilizer effectiveness and minimize negative impacts on water quality. However, Reckhow (1994) noted that limited observational data and limited scientific knowledge are often incompatible with the highly detailed model structures of pollutant fate and transport models. Consequently, uncertainty analysis is an important part of any modeling practice, as even a well validated model is prone to producing errors due to inherent variability in input and temporal parameters and model structure (Harmel and Smith, 2007).

\section{APEX}

APEX does not contain internal programs to run error and uncertainty analysis due to the complexity of the algorithms; however, external programs are readily available, such as the GLUE procedure (Beven and Binley, 1992).

\section{MIKESHE-DNDC}

The current version of MIKESHE-DNDC does not support this analysis (table 1). Sensitivity analysis and validation of Forest-DNDC were first conducted by Stange et al. (2000). Recently, Kurbatova et al. (2008) calibrated ForestDNDC using observed data for a boreal area of Russia. The model was also calibrated using observations in tropical, subtropical, and temperate regions by (Dai et al., 2012; Miehle et al., 2006; Kesik et al., 2005, 2006; Hanson et al., 2004).

\section{DRAINMOD-FOREST}

There is no error and uncertainty analysis currently built in the model (table 1). However, Tian et al. (2013b) conducted a comprehensive global sensitivity analysis for multiple long-term model predictions from DRAINMODFOREST. Results revealed the critical dominance of vegetation in regulating long-term hydrological and biogeochemical processes in forest ecosystems. Another independent, two-step global sensitivity analysis of model inputs affecting predicted nitrate losses was developed by Wang et al. (2005). The method used Latin hypercube sampling followed by a variance-based sensitivity analysis for 20 model parameters that were ranked 1 to 14 by the first step. Results of both methods indicate that the model is most sensitive to denitrification, especially the effect of temperature on processes that include organic $\mathrm{C}$ decomposition and associated $\mathrm{N}$ mineralization and immobilization. Tian et al. (2013a) also evaluated the uncertainty and equifinality of DON predictions by DRAINMOD-FOREST using the GLUE method.

DRAINMOD-W, DRAINMOD-GIS (Fernandez et al., 2007), and WATGIS are capable of performing uncertainty analyses using Latin hypercube sampling (Salas and Shin, 1999). Input parameters can include those within DRAINMOD (e.g., soil hydraulic conductivity and surface storage) and those within the stream dynamic model (e.g., channel dimensions and decay coefficient). Objective functions for the uncertainty analyses include total outflow and total load. DRAINWAT uses the @RISK tool (Palisade, 1997) in a spreadsheet independent of the model to conduct uncertainty analysis using a Monte Carlo simulation (Amatya et al., 2002, 2004). There have been extensive sensitivity analyses of input parameters in the DRAINMOD-based watershed-scale models (Kim et al., 2012; Fernandez et al., 2007; Konyha and Skaggs, 1992).

\section{REMM}

REMM has no type of built-in error analysis, but uncertainty analysis for the hydrology and water quality model components has been developed (Inamdar et al., 1999a, 1999b). A sensitivity analysis of REMM to changes in buffer characteristics with the Kolmogorov-Smirnov test was used to check for normality (Graff et al., 2005). Para- 
metric t-tests and non-parametric Mann-Whitney tests were used to investigate differences between farm outputs and a base case scenario. It was determined that when select vegetation parameters were varied, dissolved nutrients and sediment yields were highly to moderately sensitive to perturbation in rooting depth and specific leaf area, but less sensitive to changes in plant height and leaf area index. REMM has been used to help characterize the role of a buffer system on stream water quality (Bhat et al., 2007) and to examine buffer responses to varying buffer characteristics (Graff et al., 2005).

\section{SWAT}

Van Greinsven and Meixner (2006) describe several uncertainty analysis tools that have been incorporated into SWAT2005. Various types of uncertainty analyses are conducted within SWAT (Shirmohammadi et al., 2006; Benaman and Shoemaker, 2004; Lin and Radcliffe, 2006; Muleta and Nicklow, 2005; Arabi et al., 2006; Vandenberghe et al., 2001; Huisman et al., 2004; Eckhardt et al., 2003). Most recently, Pohlert et al. (2007) used a regression-based global sensitivity analysis and a GLUE approach to improve $\mathrm{N}$ predictions.

\section{ASSUMPTIONS AND LIMITATIONS APEX AND SWAT}

Limitations specific to the APEX and SWAT models include: (1) SWAT only uses MUSLE to calculate sediment loadings, while the user has a choice in APEX; (2) SWAT does not use the routing of nutrients between land unit divisions that APEX uses; (3) ALMANAC forest growth and understory growth is still being beta-tested in SWAT, and forest disturbances can only occur by linking to ALMANAC; (4) APEX and SWAT require climate station data on a daily basis, but a weather generator within the models can be used in the absence of real data (monthly data can be used to estimate daily data using a weather generator); (5) SWAT has a limited capability to simulate microbial $\mathrm{N}$ transformations, and APEX lacks bacterial simulation capability, which is currently being added; and (6) SWAT can only simulate the movement of one pesticide at a time. Both models calculate water removal via a drawdown by soil layer process.

\section{MIKESHE-DNDC}

There are several limitations to the loosely coupled MIKESHE-DNDC linkage, the most important of which is the routing of nutrients along waterways. The MIKESHE model does not simulate soil nutrient dynamics, although it simulates soil water movement and surface and groundwater flows. The DNDC model does not route water or consider physical processes for nutrient movement in water or nutrient loss into the air. Although the model simulates soil $\mathrm{N}$ dynamics and transformations in organic and inorganic pools, only total $\mathrm{N}$ loss to water is simulated as an output. Any substantial changes to MIKESHE also have to go through the MIKESHE developer, since the model is not open-source software.

\section{DRAINMOD-FOREST}

The hydrologic components, forest productivity, and $\mathrm{N}$ and $\mathrm{C}$ dynamics simulated by the DRAINMOD suite are based on the limiting assumption that a field (catchment) is drained by two parallel ditches. This suite of models is, therefore, more applicable to soils with shallow water tables on artificially drained lands with a specific ditch depth and spacing. However, a shallow ditch depth with a large spacing is generally used to simulate the hydrology of undrained agricultural and forested lands. The model is not recommended for uplands where the groundwater table is deep. DRAINMOD-FOREST has not yet been tested for forest types other than managed pine plantations.

\section{REMM}

Major assumptions and limitations to the REMM model include: (1) REMM does not simulate water, sediment, nutrient, or pesticide inputs to the buffer system; (2) REMM is fixed to a three-zone riparian buffer; (3) sheet erosion is simulated and delivered to rill channels for transport through the zone, while the rill channel is assumed to be depositing only and channel erosion is not considered; (4) output from REMM is assumed to be not impacted by a stream system, and flooding of the nearstream zone is not considered; (5) water and chemical movement to deep groundwater is considered a constant daily value if excess water is present; and (6) there is no output processing or report generated; the user is required to generate reports by processing the output data in a spreadsheet.

\section{DISCUSSION}

Although the five models (APEX, MIKESHE-DNDC, DRAINMOD-FOREST, REMM, and SWAT) seem to have the capability to simulate complete $\mathrm{N}$ and $\mathrm{C}$ processes with $\mathrm{N}$ fate and transport for a dynamic forest stand subjected to fertilization and other management practices during its life cycle, each of the models has its own benefits and limitations. For example, APEX and SWAT do not have a growth component like DRAINMOD-FOREST, MIKESHEDNDC, and REMM do; SWAT links with ALMANAC for growth. So DRAINMOD-FOREST, MIKESHE-DNDC, and REMM are perhaps more functional and effective in growth predictions than SWAT in terms of data management, processing, and direct process interactions. APEX has a multi-run function that allows for tree growth prior to other vegetation establishment or allows for the input of tree start year with a given weight and height for stand development. Because DRAINMOD-FOREST fully integrates water, $\mathrm{C}$, and $\mathrm{N}$ dynamics simultaneously, it is parameter-intensive compared to APEX and/or REMM. However, these specific evaluations were beyond the scope of this synthesis study. Unlike REMM and DRAINMODFOREST, which are field-scale models that are unable to simulate flow and $\mathrm{N}$ transport in streams and channels, MIKESHE-DNDC simulates flow in streams and channels but only total $\mathrm{N}$ flux in drainage water without considering $\mathrm{N}$ movement in soil-water and loss in the air. All of the 
currently available DRAINMOD watershed-scale models rely on empirically derived, published, or measured field $\mathrm{N}$ concentration data rather than simulating these data within the model, except for the model developed recently for agricultural lands using DRAINMOD-N II (Negm, 2011). Substituting DRAINMOD-FOREST would correct this deficiency. By contrast, MIKESHE-DNDC can simulate N fate in the soil profile, watershed-scale hydrologic processes, and GHG emissions from forested wetlands but not instream $\mathrm{N}$ routing and its transformations. However the use of MIKEBASIN (DHI, 2012) could alleviate this issue by dividing the watershed or basin into several subwatersheds or subbasins and routing the flow and $\mathrm{N}$ load along the stream channel. APEX and SWAT, both upland, field- and watershed-scale models (fig. 2) have generalized water removal drawdown processes due to their simulation scales. The automated program SWAPP (Saleh et al., 2004) was developed to convert SWAT files to and from the APEX format and simulate SWAT and APEX simultaneously to fill the gap in size coverage between the two models. A main drawback of SWAT is its inability to specifically route $\mathrm{N}$ according to where it should be (based on user knowledge of land) and track $\mathrm{N}$ transport from individual HRUs to the subwatershed outlet and overall watershed outlet. This is because SWAT's process outputs are summed and cannot be individually tracked back to a particular HRU so that it can be applied to large regions. APEX can route $\mathrm{N}$ according to a specified path, and while it can also sum its results at the subwatershed and watershed levels, particular $\mathrm{N}$ loadings can be tracked back to the source from which they originated, readily allowing for problem detection.

Among all the five models, only DRAINMOD-FOREST has been tested for its ability to predict the effects of fertilization on $\mathrm{N}$ fate using long-term data, but only on a small watershed without channel transport and containing a single soil type (Tian et al., 2012b). APEX has been tested mostly for sediment loads, pesticides, N, P, and its hydrologic fractions. The potential of MIKESHE-DNDC to predict forest fertilization effects was demonstrated by Farahbakhshazad et al. (2008). REMM depends on upland inputs, and SWAT does not have a forest growth component and sums HRU outputs to simulate total $\mathrm{N}$ load at the watershed outlet.

All the models, except DRAINMOD-FOREST, are built with a user-friendly GIS interface capable of creating spatial data and output variables of interest on a grid/cell or polygon/subwatershed and also the whole watershed basis. Although such an interface is not required for field-scale analysis, it is generally required for landscape-scale $(\sim 50$ $\mathrm{km}^{2}$ ) studies and is a benefit for model users.

Other important factors that land managers are interested to learn from these model applications are the proportion of fertilizer $\mathrm{N}$ that leaches beyond the forest floor and reaches the stream (water bodies), the portion retained in the soil profile, and the sinks (uptake) such as trees and understory, including the impacts of various management practices such as competition control, multiple fertilizer applications, residue removal, and prescribed burning, in addition to harvesting. The models reviewed here may provide differ- ent outputs for the same inputs as a result of these management impacts based on their respective process equations and the associated parameters embedded within the equations. One reason for this is that empirical data collected at a few locations do not meet the needs of modelers attempting to integrate across temporal and spatial scales (Wallenstein et al., 2012), thus limiting the applicability of models to simulate physical processes adequately. Accordingly, Wallenstein et al. (2012) noted that model development should occur in tandem with experimental design and data acquisition. However, the required data are not always available or are very difficult to acquire, and the best possible decisions are made regarding what to incorporate into the model so that the project's objectives can be addressed. Over time, as data become available, empirical processes can be replaced by more physically based processes and equations.

\section{Summary ANd Perspectives}

In order to address water quality issues including the fate of $\mathrm{N}$ fertilizer within a large landscape, simulation models that have functional abilities at scales $>50 \mathrm{~km}^{2}$ are needed. From the process perspective, hydrology and instream flow routing are the key driving variables for accurately predicting both $\mathrm{N}$ cycling and transport processes on that scale. Accordingly, the applicability of each model is influenced by the scale, climate, topography, and experimental data from which its processes were developed. Although the model comparisons presented here may not be complete, they provide a basis for objective comparison of the models and for expanding the comparison with other aspects of modeling, including model complexity, as suggested by Borah and Bera (2003). In general, models using approximate equations with analytical solutions may provide a balance between complexity and accuracy (Borah, 2011), as is the case with DRAINMOD.

DRAINMOD-FOREST was developed for predicting hydrology of a field on poorly drained, lowland soils in a wide range of geographical locations; hence, it should not be expected to function well in watersheds containing a mosaic of upland and wetlands soils across a topographic gradient and drainage network. In contrast, APEX and SWAT were developed for a wide range of landscapes and watersheds, respectively, with drainage networks but incorporating processes primarily reflecting upland soil conditions. MIKESHE-DNDC is well suited for considering the spatial arrangement of upland and wetland soils within a landscape (Dai et al., 2012), but the absence of $\mathrm{N}$ export and in-stream processes warrants consideration. REMM contains the requisite functionality of both the upland and wetland soils; its constraint is in the scale of application, by design. Accordingly, it is best coupled with another model when considering simulations at the landscape scale.

The strengths of the models reflect their original design intent. DRAINMOD-FOREST was designed as a fieldscale forest hydrology model, with the $\mathrm{N}$ cycling and productivity modules added. Similarly, REMM was designed specifically to consider the interface of the upland 
fields with the riparian zone to focus on the transport through the riparian zone to the stream at the field scale. In contrast to DRAINMOD-FOREST, REMM does have provisions for both upland and wetland soil processes. Neither of these models was designed for application at a large scale $\left(>50 \mathrm{~km}^{2}\right)$, nor were provisions for in-stream transformation, routing, and transport processes considered. MIKESHE is a robust hydrologic model designed for landscape-scale assessments. When coupled with ForestDNDC, the linked model can be used to simulate $\mathrm{C}$ and $\mathrm{N}$ dynamics in both upland and wetland soils. This linked model application has only been evaluated recently, and it merits further consideration since each of the component models contain processes to describe water, $\mathrm{C}$, and $\mathrm{N}$ cycles; however, that consideration would benefit from inclusion of the in-stream routing provisions currently available in MIKEBASIN. SWAT was designed for large-scale watersheds $\left(>4000 \mathrm{~km}^{2}\right)$ and uses a lumped approach for simulating nutrient fate and transport processes. Incorporation of anaerobic soil processes and their testing is needed to better substantiate the use of the model in watersheds consisting of a mosaic of upland and wetland soils. Correspondingly, validation of BMP effectiveness simulations should improve consideration of hydric soils, as in REMM. APEX was designed to address sediment and nutrient transport in upland forests; hence, its strength is the routing and process functions. Inclusion of forest overstory and understory vegetation as a driver of $\mathrm{N}$ dynamics is a desirable attribute. Both SWAT and APEX can simulate BMPs without linking to REMM, but physical and chemical processes are reflected in the results differently due to the different spatial scales simulated by each model.

Our assessment reinforces the well-established notion that care must be taken when selecting a model for an intended application. Based on this comparison of the model configurations, none of the five models that we considered is yet adequate to address the fate of $\mathrm{N}$ fertilizers applied to forest stands within the southeastern U.S. at a landscape scale (e.g., $\sim 50 \mathrm{~km}^{2}$ ). While efforts are underway to extend their capabilities and address their limitations, care must be given to discern whether the underlying limitations have been allayed or the developments have been built on a weak foundation. For example, DRAINMOD-N II was recently linked with flow routing and transport modules to assess the $\mathrm{N}$ fate and transport on a $6500 \mathrm{ha}\left(65 \mathrm{~km}^{2}\right)$ mixed forested and agricultural watershed in North Carolina (Negm, 2011), but the model is still constrained to lowland soils and so cannot be appropriately applied to a watershed with a mosaic of drainage classes. Advancements in SWAT include subsurface tile flow using Hooghoudt's and Kirkham equations from a DRAINMOD subroutine (Moriasi et al., 2011, 2012) for poorly drained soils. Direct considerations of processes that occur in various landscape positions, including riparian buffers (Bonumá, 2011; Bosch et al., 2010; Liu et al., 2007), may provide opportunities to test and apply it as a comprehensive model of $\mathrm{N}$ fate and transport in both upland and lowland terrestrial ecosystems for large-scale watersheds. While REMM can continue to function as a stand-alone model for assessing riparian buffer and BMP effectiveness, efforts are underway to link
REMM with the upland components of SWAT. However, SWAT will have to incorporate capabilities to simulate forest and understory growth, either within the model itself or linking with the APEX and/or ALMANAC module to better reflect changes in $\mathrm{N}$ cycle during stand development.

This assessment considers the functionality of the five models from a conceptual perspective; it is constrained by the lack of performance-driven assessment of these models and the omission of models that may be appropriate. The development of a common database that could be used to directly compare model performance at a large scale $\left(\sim 50 \mathrm{~km}^{2}\right)$ is a critical need. Direct comparison of results from model applications on a common landscape facilitates assessment of performance without the complications of comparisons among different applications. That watershed $\left(\sim 50 \mathrm{~km}^{2}\right)$ database should include multiple soils types, multiple drainage classes, a defined drainage network, multiple forest types on uplands, lowlands, or both, and longterm records of hydrology, water quality, and forest growth. Each of these models continues to be improved for new applications and situations; however, unless a common database is used for assessment purposes, it will be difficult to discern if the whole is equally as good as the sum of the parts. Accordingly, long-term watershed research sites maintained by agencies (U.S. Geological Survey, USDA Agricultural Research Service, U.S. Forest Service, academia, and other agencies) should be organized to make comprehensive databases available for testing these ecohydrology models.

\section{ACKNOWLEDGEMENTS}

We would like to acknowledge the American Geophysical Union (AGU) for publicizing the outcome of the workshop on "Challenges in Modeling the Fate of Nitrogen Applied to Forests" in EOS (available at: www.agu.org/pubs/ crossref/2008/2008EO240006.shtml). We would also like to thank Dr. Jim Kiniry at the USDA-ARS, Dr. Brett Watson at the University of Saskatchewan, Dr. Deva Borah, formerly at Woolpert, Inc., and the three anonymous reviewers of this manuscript for their constructive suggestions and comments that enhanced the quality of the manuscript.

\section{REFERENCES}

Abdelnour, A., M. Stieglitz, F. Pan, and R. McKane. 2011. Catchment hydrological responses to forest harvest amount and spatial pattern. Water Resour. Res. 47(9): W09521, doi: 1029/2010WR010165.

Aber, J. D., and C. A. Federer. 1992. A generalized, lumpedparameter model of photosynthesis, evaporation, and net primary production in temperate and boreal forest ecosystems. Oecologia 92(4): 463-474.

Aber, J. D., P. B. Reich, and M. L. Goulden. 1996. Extrapolating leaf $\mathrm{CO}_{2}$ exchange to the canopy: A generalized model of forest photosynthesis compared with measurements by eddy correlation. Oecologia 106(2): 257-265.

Aber, J. D., S. V. Ollinger, and C. T. Driscoll. 1997. Modeling nitrogen saturation in forest ecosystems in response to land use and atmospheric deposition. Ecol. Model. 101(1): 61-78.

Aber, J. D., S .V. Ollinger, C. T. Driscoll, C. A. Federer, and P. B. 
Reich. 2005. PnET models: Carbon, nitrogen, water dynamics in forest ecosystems (ver. 4/5). Oak Ridge, Tenn.: Oak Ridge National Laboratory. Available at: http://daac.ornl.gov.

Ahonen, J., K. Rankinen, M. Holmberg, S. Syri, and M. Forsius. 1998. Application of the SMART2 model to a forested catchment in Finland: Comparison of the SMART model and effects of emission reduction scenarios. Boreal Environ. Res. 3(3): 221-233.

Alexander, R. B., P. J. Johnes, E. W. Boyer, and R. A. Smith. 2002. A comparison of models for estimating the riverine export of nitrogen from large watersheds. Biogeochemistry 57-58: 295339.

Altier, L. S., R. Lowrance, R. G. Williams, S. P. Inamdar, D. D. Bosch, J. M. Sheridan, R. K. Hubbard, and D. L. Thomas. 2002. Riparian Ecosystem Management Model: Simulator for ecological processes in riparian zones. Conservation Research Report 46. Washington, D.C.: USDA-ARS.

Amatya, D. M., and R. W. Skaggs. 2001. Hydrologic modeling of a drained pine plantation on poorly drained soils. Forest $S c i$. 47(1): 103-114.

Amatya, D. M., and R. W. Skaggs. 2011. Long-term hydrology and water quality of a drained pine plantation in North Carolina. Trans. ASABE 54(6): 2087-2098.

Amatya, D. M., R. W. Skaggs, and J. D. Gregory. 1997. Evaluation of a watershed-scale forest hydrologic model. J. Agric. Water Mgmt. 32(3): 239-258.

Amatya, D. M., G. M. Chescheir, R. W. Skaggs, G. P. Fernandez, and J. W. Gilliam. 2002. Watershed analysis and treatment evaluation routine in spreadsheet (WATERS). In Proc. Conf. on Watershed Management to Meet Emerging TMDL Environmental Regulations, 490-495. St. Joseph, Mich.: ASAE.

Amatya, D. M., G. M. Chescheir, G. P. Fernandez, R. W. Skaggs, F. Birgand, and J. W. Gilliam. 2003. Lumped parameter models for predicting nitrogen loading from lower coastal plain watersheds. Report No. 347. Raleigh, N.C.: University of North Carolina, Water Resources Research Institute.

Amatya, D. M., G. M. Chescheir, G. P. Fernandez, R. W. Skaggs, and J. W. Gilliam. 2004. DRAINWAT-based methods for estimating nitrogen transport in poorly drained soils. Trans. ASAE 43(3): 677-687.

Amatya, D. M., G. Sun, R. W. Skaggs, G. M. Chescheir, and J. E. Nettles. 2006. Hydrologic effects of global climate change on a large drained pine forest. In Proc. Intl. Conf. on Hydrology and Management of Forested Wetlands, 383-394. T. Williams and J, Nettles, eds. St. Joseph, Mich.: ASABE.

Amoah, J., D. M. Amatya, and S. Nnaji. 2013. Quantifying watershed depression storage: Determination and application in a hydrologic model. Hydrol. Proc. 27(17): 2401-2413.

Anderson, C. 2002. Ecological effects on streams from forest fertilization: Literature review and conceptual framework for future study in the western. USGS Water Resources Investigations Report 01-4047. Reston, Va.: U.S. Geological Survey, in cooperation with Bureau of land Management, Portland, Oregon.

Arabi, M., R. S. Govindaraju, M. M. Hantush, and B. A. Engel. 2006. Role of watershed subdivision on modeling the effectiveness of best management practices with SWAT. $J$. American Water Resour. Assoc. 42(2): 513-528.

Arnold, J. G., R. Srinivasan, R. S. Muttiah, and J. R. Williams. 1998. Large-area hydrological modeling and assessment: Part I. Model development. J. American Water Resour. Assoc. 34 (1): 73-89.

Bagnold, R. A. 1977. Bed transport by natural rivers. Water Resour. Res. 13(2): 303-312.

Bechtold, I., S. Kohne, M. A. Youssef, B. Lennartz, and R. W. Skaggs. 2007. Simulating nitrogen leaching and turnover in a subsurface-drained grassland receiving animal manure in northern Germany using DRAINMOD-N II. Agric. Water Mgmt. 93(1-2): 30-44.

Beltran, B., D. M. Amatya, M. A. Youssef, M. Jones, R. W. Skaggs, T. J. Callahan, and J. E. Nettles. 2010. Impacts of fertilization additions on water quality of a drained pine plantation in North Carolina: A worst-case scenario. J Environ. Qual. 39(1): 293303.

Benaman, J., and C. A. Shoemaker. 2004. Methodology for analyzing ranges of uncertain model parameters and their impact on total maximum daily load processes. J. Environ. Eng. 130(6): 648-656.

Beven, K. J., and A. M. Binley. 1992. The future of distributed models: Model calibration and uncertainty prediction. Hydrol. Proc. 6(3): 279-298.

Bhat, S., K. Hatfield, J. Jacobs, R. R. Lowrance, and R. G. Williams. 2007. Surface runoff contribution of nitrogen during storm events in a forested watershed: Application of the Riparian Ecosystem Management Model (REMM). Biogeochemistry 85(3): 253-262.

Binkley, D., H. Burnham, and H. L. Allen. 1999. Water quality impacts of forest fertilization with nitrogen and phosphorus. Forest Ecol. Mgmt. 121(3): 191-213.

Binkley, D., G. G. Ice, J. Kaye, and C. A. Williams. 2004. Nitrogen and phosphorus concentrations in forest streams of the United States. J. American Water Resour. Assoc. 40(5): 1277-1291.

Birgand, F., R. W. Skaggs, G. M. Chescheir, and J. W. Gilliam. 2007. Nitrogen removal in streams of agricultural catchments: A literature review. Crit. Rev. Environ. Sci. Tech. 37(5): 381-487.

Bonumá, N. B. 2011. Modeling of water, sediment, and phosphorus loads in an agricultural watershed in southern Brazil. $\mathrm{PhD}$ diss. Santa Maria, Brazil: Universidade Federal de Santa Maria.

Borah, D. K. 2011. Hydrologic procedures of storm event watershed models: A comprehensive review and comparison. Hydrol. Proc. 25(22): 3472-3489.

Borah, D. K., and M. Bera. 2003. Watershed-scale hydrologic and nonpoint-source pollution models: Review of mathematical bases. Trans. ASAE 46(6): 1553-1566.

Borah, D. K., G. Yagow, A. Saleh, P. L. Barnes, W. Rosenthal, E. C. Krug, and L. M. Hauck. 2006. Sediment and nutrient modeling for TMDL development and implementation. Trans. ASABE 49(4): 967-986.

Bosch, D. D., J. G. Arnold, M. Volk, and P. M. Allen. 2010. Simulation of a low-gradient coastal plain watershed using the SWAT landscape model. Trans. ASABE 53(5): 1445-1456.

Breeman, N. V., E. W. Boyer, C. L. Goodale, N. A. Jaworski, K. Paustian, S. P. Seitzinger, K. Lajtha, B. Mayer, D. Van Dam, R. W. Howarth, K. J. Nadelhoffer, M. Eve, and G. Billen. 2002. Where did all the nitrogen go? Fate of nitrogen inputs to large watersheds in the northeastern USA. Biogeochemistry 57-58: 267-293.

Breve, M. A., R. W. Skaggs, J. E. Parsons, and J. W. Gilliam. 1997. DRAINMOD-N: A nitrogen model for artificially drained soils. Trans. ASAE 40(4): 1067-1075.

Butts, M. B., J. T. Payne, M. Kristensen, and H. Madsen. 2004. An evaluation of the impact of model structure on hydrological modeling uncertainty for streamflow simulation. J. Hydrol. 298(1-4): 242-266.

Chescheir, G. M., D. M. Amatya, and R. W. Skaggs. 1994. Modeling the hydrology of a natural wetland. ASAE Paper No. 942597. St. Joseph, Mich.: ASAE.

Comins, H. N., and R. E. McMurtrie. 1993. Long-term response of nutrient-limited forests to $\mathrm{CO}_{2}$ enrichment: Equilibrium behavior of plant-soil models. Ecol. Appl. 3(4): 666-681.

Cough, C. M., J. R. Seiler, and C. A Maier. 2004. Short-term effects of fertilization on loblolly pine (Pinus taeda L.) physiology. 
Plant Cell Environ. 27(7): 876-886.

Cui, J., C. Li, and C. Trettin. 2005a. Analyzing the ecosystem carbon and hydrologic characteristic of forested wetland using a biogeochemical process model. Global Change Biol. 11(2): 278289.

Cui, J., C. Li, G. Sun, and C. Trettin. 2005b. Linkage of MIKE SHE to Wetland-FNDC for carbon budgeting and anaerobic biogeochemistry simulation. Biogeochemistry 72(2): 147-167.

Dai, Z., C. C. Trettin, C. Li, H. Li, G. Sun, and D. M. Amatya. 2012. Effect of assessment scale on spatial and temporal variations in $\mathrm{CH}_{4}, \mathrm{CO}_{2}$, and $\mathrm{N}_{2} \mathrm{O}$ fluxes in a forested wetland. Water Air Soil Poll. 223(1): 253-265.

Dai, Z., C. C. Trettin, and D. M. Amatya. 2013. Effects of climate variability on forest hydrology and carbon sequestration on the Santee Experimental Forest in coastal South Carolina. USDA Forest Service South. Res. Station, Gen. Tech. Rep. SRS-172.

Delgado, J. A. 2002. Quantifying the loss mechanisms of nitrogen. J. Soil and Water Cons. 57(6): 389-398.

Del Grosso, S. J., W. J. Parton, A. R. Mosier, M. D. Hartman, J. Brenner, D. S. Ojima, and D. S. Schimel. 2001. Simulated interaction of carbon dynamics and nitrogen trace gas fluxes using the DAYCENT model. In Modeling Carbon and Nitrogen Dynamics for Soil Management, 303-332. M. Schaffer, L. Ma, and S. Hansen, eds. Boca Raton, Fla.: CRC Press.

DHI. 2005. MIKE SHE technical reference. Horsholm, Denmark, Danish Hydraulic Institute, DHI Water and Environment.

DHI. 2012. MIKE BASIN: An integrated river basin planning and management tool. Horsholm, Denmark, Danish Hydraulic Institute, DHI Water and Environment.

Diggs, J. A. 2004. Simulation of nitrogen and hydrology loading of forested fields in eastern North Carolina using DRAINMOD-N II. MS thesis. Raleigh, N.C.: North Carolina. State University, Department of Biological and Agricultural Engineering.

Douglas-Mankin, K. R., R. Srinivasan, and J. G. Arnold. 2010. Soil and water assessment tool (SWAT) model: Current developments and applications. Trans. ASABE 53(5): 14231431.

Ducey, M., and L. Allen. 2001. Nutrient supply and fertilization efficiency in midrotation loblolly pine plantations: A modeling analysis. Forest Sci. 47(1): 96-102.

Eckersten, H., and C. Beier. 1998. Comparison of N and C dynamics in two Norway spruce stands using a process-oriented simulation model. Environ. Pollut. 102(1): 395-401.

Eckhardt, K., L. Breuer, and H.-G. Frede. 2003. Parameter uncertainty and the significance of simulated land use change effects. J. Hydrol. 273(1-4): 164-176.

El-Kadi, A. I., and G. Ling. 1999. LPM-N: A lumped parameter model for nitrogen leaching in agricultural lands. Groundwater 37(1): 27-32.

El-Sadek, A., K. Oorts, L. Sammels, A. Timmerman, M. Radwan, and J. Feyen. 2003. Comparative study of two nitrogen models. J. Irrig. Drain. Eng. 129(1): 44-52.

Farahbakhshazad, N., D. L. Dinnes, C. Li, D. B. Jaynes, and W. Salas. 2008. Modeling biogeochemical impacts of alternative management practices for a row-crop field in Iowa. Agric. Ecosystems and Environ. 123(1-3): 30-48.

Fernandez, G. P., G. M. Chescheir, R. W. Skaggs, and D. M. Amatya. 2002. WATGIS: A GIS-based lumped parameter water quality model. Trans. ASAE 45(3): 593-600.

Fernandez, G. P., G. M. Chescheir, R. W. Skaggs, and D. M. Amatya. 2005. Development and testing of watershed-scale models for poorly drained soils. Trans. ASAE 48(2): 639-652.

Fernandez, G. P., G. M. Chescheir, R. W. Skaggs, and D. M. Amatya. 2006. DRAINMOD-GIS: A lumped parameter watershed-scale drainage and water quality model. Agric. Water Mgmt. 81(1-2): 77-97.
Fernandez, G. P., G. M. Chescheir, R. W. Skaggs, and D. M. Amatya. 2007. Application of DRAINMOD-GIS to a lower coastal plain watershed. Trans. ASABE 50(2): 439-447.

Fouss, J. L., R. L. Bengtson, and C. E. Carter. 1987. Simulating subsurface drainage in the lower Mississippi Valley with DRAINMOD. Trans. ASAE 30(6): 1679-1688.

Fox, T. R., E. J. Jokela, and H. L. Allen. 2007. The development of pine plantation silviculture in the southern United States. $J$. Forestry 105(7): 337-347.

Gassman, P. W., J. R. Williams, V. W. Benson, R. C. Izaurralde, L. M. Hauck, C. A. Jones, J. D. Atwood, J. R. Kiniry, and J. D. Flowers. 2005. Historical development and applications of the EPIC and APEX models. Working Paper 05-WP 397. Ames, Iowa: Iowa State University, Center for Agricultural and Rural Development.

Gassman, P. W., M. R. Reyes, C. H. Green, and J. G. Arnold. 2007. The Soil and Water Assessment Tool: Historical development, applications, and future directions. Trans. ASABE 50(4): 12111250.

Godwin, D. C., and C. A. Jones. 1991. Nitrogen dynamics in soilplant systems. In Modeling Plant and Soil Systems, 287-321. J. Hanks and J. T. Ritchie, eds. Madison, Wisc.: ASA-CSSASSSA.

Gorissen, A., J. H. van Ginkel, J. J. B. Keurentjes, and J. A. van Veen. 1995. Grass root decomposition is retarded when grass has been grown under elevated $\mathrm{CO}_{2}$. Soil Biol. and Biochem. 27(1): 117-120.

Grace, J. M., III, R. W. Skaggs, and D. K. Cassel. 2007. Influence of thinning loblolly pine (Pinus taeda L.) on hydraulic properties of an organic soil. Trans. ASABE 50(2): 517-522.

Graff, C. D., A. M. Sadeghi, R. R. Lowrance, and R. G. Williams. 2005. Quantifying the sensitivity of the Riparian Ecosystem Management Model (REMM) to changes in climate and buffer characteristics common to conservation practices. Trans. ASAE 48(4): 1377-1387.

Graham, D. N., and M. B. Butts. 2005. Chapter 10: Flexible integrated watershed modeling with MIKE SHE. In Watershed Models, 245-272. V. P. Singh and D. K. Frevert, eds. Boca Raton, Fla.: CRC Press.

Green, W. H., and G. A. Ampt. 1911. Studies on soil physics: 1. Flow of air and water through soils. J. Agric. Sci. 4(1): 1-24.

Gusman, A. J., and M. A. Marino. 1999. Analytical modeling of nitrogen dynamics in soils and groundwater. J. Irrig. Drain. Eng. 125(6): 330-337.

Hanson, P. J., J. S. Amthor, S. D. Wullschleger, K. B. Wilson, R. F. Grant, A. Hartley, D. Hui, E. R. Hunt, D. W. Johnson Jr., J. S. Kimball, A. W. King, Y. Lou, S. G. McNulty, G. Sun, P. E. Thornton, S. Wang, M. Williams, D. D. Baldocchi, and R. M. Cushman. 2004. Oak forest carbon and water simulations: Model intercomparisons and evaluations against independent data. Ecol. Monogr. 74(3): 443-489.

Harder, S. V., D. M. Amatya, T. J. Callahan, and C. C. Trettin. 2006. Modeling monthly water budget of a first-order coastal forested watershed. In Proc. Intl. Conf. on Hydrology and Management of Forested Wetlands, 218-230. T. M. Williams and J. E. Nettles, eds. St. Joseph, Mich.: ASABE.

Harmel, R. D., and P. K. Smith. 2007. Consideration of measurement uncertainty in the evaluation of goodness-of-fit in hydrologic and water quality modeling. J. Hydrol. 337(3-4): 326-336.

Hénin, S., and M. Dupuis. 1945. Essai de bilan de la metière organique du sol. Ann. Agron. 15: 17-29.

Hooghoudt, S. B. 1940. Algemene beschouwing van het probleem van de detailontwatering en de infiltratie door middel van parallel loopende drains, greppels, slooten en kanalen. No. 7 in de serie: Bijdragen tot de kennis van eenige natuurkundige 
grootheden van den grond. Bodemkundig Instituut te Groningen. Rijksuitgeverij Dienst van de Nederlandse Staatscourant. The Hague, The Netherlands: Algemeene Landsdrukkerij.

Huisman, J. A., L. Breuer, and H.-G. Frede. 2004. Sensitivity of simulated hydrological fluxes towards changes in soil properties in response to land use change. Phys. Chem. Earth A/B/C 29(1112): 749-758.

Hwang, T., L. Band, and T. C. Hales. 2009. Ecosystem processes at the watershed scale: Extending optimality theory from plot to catchment. Water Resour. Res. 45(11): W11425, doi: 10.1029/2009WR007775.

Ice, G. G., and J. D. Stednick, eds. 2004. A Century of Forest and Wildland Watershed Lessons. Bethesda, Md.: Society of American Foresters.

Ice, G., E. Schilling, and J. Vowell. 2010. Trends for forestry best management practices implementation. J. Forestry 108(6): 267273.

Inamdar, S. P., J. M. Sheridan, R. R. Lowrance, R. G. Williams, D. D. Bosch, L. S. Altier, and D. L. Thomas. 1999a. Riparian Ecosystem Management Model (REMM): I. Testing of the hydrology component for a coastal plain riparian system. Trans. ASAE 42(6): 1679-1689.

Inamdar, S. P., R. R. Lowrance, L. S. Altier, R. G. Williams, and R. K. Hubbard. 1999b. Testing of the water quality and nutrient cycling component for a coastal plain riparian system. Trans. ASAE 42(6): 1691-1707.

Izaurralde, R. C., J. R. Williams, W. B. McGill, N. J. Rosenberg, and M. C. Quiroga Jakas. 2006. Simulating soil C dynamics with EPIC: Model description and testing against long-term data. Ecol. Model. 192(3-4): 362-384.

Izaurralde, R. C., W. B. McGill, and J. R. Williams. 2012. Development and application of the EPIC model for carbon cycle, greenhouse gas mitigation, and biofuel studies. In Managing Agricultural Greenhouse Gases: Coordinated Agricultural Research through GRACEnet to Address our Changing Climate, 409-429. M. A. Liebeg, ed. San Diego, Cal.: Academic Press.

Jenkins, A., R. C. Ferrier, and R. C. Helliwell. 2001. Modeling nitrogen dynamics at Lochnagar, N.E. Scotland. Hydrol. Earth Syst. Sci. 5(3): 519-527.

Johanson, R. C., J. C. Imhoff, H. H. Davis, J. L. Kittle, and A. S. Donigian. 1981. User's manual for Hydrologic Simulation Program-Fortran (HSPF). Release 7.0. Athens, Ga.: U.S. Environmental Protection Agency.

Johnson, B. E., and T. K. Gerald. 2006. Development of nutrient submodules for use in the Gridded Surface Subsurface Hydrologic Analysis (GSSHA) distributed watershed model. $J$. American Water Resour. Assoc. 42(6): 1503-1525.

Johnson, D. W., T. Sogn, and S. Kvindesland. 2000. The nutrient cycling model: Lessons learned. Forest Ecol. Mgmt. 138(1-3): 91-106.

Kandil, H. M., R. W. Skaggs, S. A. Dayem, and Y. Aiad. 1995. DRAINMOD-S: A water management model for irrigated arid lands, crop yield, and applications. J. Irrig. Drain. Sys. 9(3): 239-258.

Kemanian, A. R., and C. O. Stöckle. 2010. C-Farm: A simple model to evaluate the carbon balance of soil profiles. European $J$. Agron. 32(1): 22-29.

Kemanian, A. R., S. Julich, V. S. Manoranjan, and J. R. Arnold. 2011. Integrating carbon, nitrogen, and phosphorus cycling in the watershed model SWAT: theory and model testing. Ecol. Model. 222(12): 1913-1921.

Kesik, M., P. Ambus, R. Baritz, N. Bruggemann, K. ButterbachBahl, M. Damm, J. Duyzer, L. Horvath, R. Kiese, B. Kitzler, A Leip, C. Li, M. Pihlatie, K. Pilegaard, G. Seufert, D. Simpson, U. Skiba, G. Smiatek, T. Vesala, and S. Zechmeister-Boltenstern.
2005. Inventories of $\mathrm{N}_{2} \mathrm{O}$ and $\mathrm{NO}$ emissions from European forest soils. Biogeosciences 2(4): 353-375.

Kesik, M., N. Brüggemann, R. Forkel, R. Kiese, R. Knoche, C. Li, G. Seufert, D. Simpson, and K. Butterbach-Bahl. 2006. Future scenarios of $\mathrm{N}_{2} \mathrm{O}$ and $\mathrm{NO}$ emissions from European forest soils. J. Geophys. Res. 111(G2): 2018-2022.

Kim, H. W., D. M. Amatya, S. W. Broome, D. L. Hesterberg, and M. Choi. 2012. Sensitivity analysis of the DRAINWAT model applied to an agricultural watershed in the lower coastal plain, North Carolina, USA. Water Environ. J. 26(1): 130-145.

Kim, H. W., D. M. Amatya, R. W. Skaggs, and G. M. Chescheir. 2013. Hydrologic effects of size and location of fields converted from drained pine forest into agricultural cropland. J. Hydrol. Eng. 18(5): 552-566.

Kiniry, J. R., J. R. Williams, P. W. Gassman, and P. Debaeke. 1992. A general, process-oriented model for two competing plant species. Trans. ASAE 35(3): 801-810.

Kiniry, J. R., J. D. MacDonald, A. R. Kemanian, B. Watson, and G. Putz. 2008. Plant growth simulation for landscape-scale hydrologic modeling. Hydrol. Sci. J. 53(5): 1030-1042.

Kirkham, D. 1957. Theory of land drainage. In Drainage of Agricultural Lands, 139-181 J. N. Luthin, ed. Agronomy Monograph 7. Madison, Wisc.: ASA.

Kjonaasn, O. J., and R. F. Wright. 1998. Nitrogen leaching from Nlimited forest ecosystems: The MERLIN model applied to Gardsjon, Sweden. Hydrol. Earth Syst. Sci. 2(4): 415-429.

Knisel, W. G. 1980. CREAMS: A field-scale model for chemicals, runoff, and erosion from agricultural management systems. Conservation Research Report 26. Washington, D.C.: USDA.

Konyha, K. D., and R. W. Skaggs. 1992. A coupled, field hydrology open channel flow model: Theory. Trans. ASAE 35(5): 14311440.

Koskela, J. 2000. A process-based growth model for the grass stage pine seedlings. Silva Fennica 34(1): 3-20.

Kristensen, K. J., and S. E. Jensen. 1975. A model for estimating actual evapotranspiration from potential evapotranspiration. Nordic Hydrol. 6(3): 170-188.

Kurbatova, J., C. Li, A. Yarlagin, X. Xiao, and N. Vygodskaya. 2008. Modeling carbon dynamics in two adjacent spruce forests with different soil conditions in Russia. Biogeosciences 5(1): 969-980.

Landsberg, J. J., and R. H. Waring. 1997. A generalized model of forest productivity using simplified concepts of radiation use efficiency, carbon balance, and partitioning. Forest Ecol. Mgmt. 95(3): 209-228.

Lauren, A., L. Finer, H. Koivusalo, T. Kokkonen, T. Farvonen, S. Kellomaki, H. Mannerkoski, and M. Ahtiainen. 2005. Water and nitrogen processes along a typical flowpath and streamwater exports from a forested catchment and changes after clearcutting: A modeling study. Hydrol. Earth Syst. Sci. 9(6): $657-$ 674.

Li, C. 2007. Quantifying greenhouse gas emissions from soils: Scientific basis and modeling approach. Soil Sci. and Plant Nutr. 53(4): 344-352.

Li, C., S. Frolking, and T. A. Frolking. 1992. A model of nitrous oxide evolution from soil driven by rainfall events: 1. Model structure and sensitivity. J. Geophys. Res. 97(D9): 9759-9776.

Li, C., S. Frolking, and R. Harriss. 1994. Modeling carbon biogeochemistry in agricultural soils. Global Biogeochem. Cycl. 8(3): 237-254

Li, C., J. Aber, F. Stange, K. Butterbach-Bahl, and H. Papen. 2000. A process-oriented model of $\mathrm{N}_{2} \mathrm{O}$ and $\mathrm{NO}$ emissions from forest soils: 1. Model development. J. Geophys. Res. 105(D4): 43694384

Li, C., J. Cui, G. Sun, and C. Trettin. 2004a. Modeling impacts of management on carbon sequestration and trace gas emissions in 
forested wetland ecosystems. Environ. Mgmt. 33(1): 176-186.

Li, X., R. B. Ambrose, and R. Araujo. 2004b. Modeling mineral nitrogen export from a forest terrestrial ecosystem to streams. Trans. ASAE 47(3): 727-739.

Lin, Z., and D. E. Radcliffe. 2006. Automatic calibration and predictive uncertainty analysis of a semidistributed watershed model. Vadose Zone J. 5(1): 248-260.

Ling, G., and A. I. El-Kadi. 1998. A lumped parameter model for nitrogen transformation in the unsaturated zone. Water Resour. Res. 34(2): 203-212.

Linn, D. M., and J. W. Doran. 1984. Effect of water-filled pore space on carbon dioxide and nitrous oxide production in tilled and non-tilled soils. SSSA J. 48(6): 1267-1272.

Liu, Y., W. Yang, and X. Wang. 2007. GIS-based integration of SWAT and REMM for estimating water quality benefits of riparian buffers in agricultural watersheds. Trans. ASABE 50(5): 1549-1563.

Lowrance, R. R., and J. M. Sheridan. 2005. Surface runoff water quality in a managed three-zone riparian buffer. J. Environ. Qual. 34(5): 1851-1859.

Lowrance, R., L. S. Altier, R. G. Williams, S. P. Inamdar, J. M. Sheridan, D. D. Bosch, R. K. Hubbard, and D. L. Thomas. 2000. REMM: The Riparian Ecosystem Management Model. J. Soil Water Cons. 55(1): 27-34.

Lu, J., G. Sun, S. G. McNulty, and N. Comerford. 2009. Sensitivity of pine flatwoods hydrology to climate change and forest management in Florida, USA. Wetlands 29(3): 826-836.

Lunn, R. J., R. Adams, R. Mackay, and S. M. Dunn. 1996. Development and application of a nitrogen modeling system for large catchments. J. Hydrol. 174(3-4): 285-304.

MacDonald, J. D., J. R. Kiniry, G. Putz, and E. E. Prepas. 2008. A multi-species, process-based vegetation simulation module to simulate successional forest regrowth after forest disturbance in daily time step hydrological transport models. J. Environ. Eng. Sci. 7(S1): 1-18.

McBroom, M. W., R. S. Beasley, M. Chang, and G. G. Ice. 2008. Storm runoff and sediment losses from forest clear cutting and stand re-establishment. Hydrol. Proc. 22(10): 1509-1522.

McCarthy, E. J., J. W. Flewelling, and R. W. Skaggs. 1992. Hydrologic model for drained forested watershed. J. Irrig. Drain. Eng. 118(2): 242-255.

McLaren, A. D. 1970. Temporal and vectorial reactions of nitrogen in soil: A review. Canadian J. Soil Sci. 50(2): 97-109.

Miehle, P., S. J. Livesley, C. Li, P. M. Feikema, M. A. Adams, and S. K Arndt. 2006. Quantifying uncertainty from large-scale model predictions of forest carbon dynamics. Global Change Biol. 12(8): 1421-1434.

Moriasi, D. N., J. G. Arnold, G. G. Vazquez-Amabile, and B. A. Engel. 2011. Shallow water table depth algorithm in SWAT: Recent developments. Trans. ASABE 54(5): 1705-1711.

Moriasi, D. N., C. G. Rossi, J. G. Arnold, and M. D. Tomer. 2012. Evaluating hydrology of the Soil and Water Assessment Tool (SWAT) with new tile drain equations. J. Soil Water Cons. 67(6): 513-524.

Muleta, M. K., and J. W. Nicklow. 2005. Sensitivity and uncertainty analysis coupled with automatic calibration for a distributed watershed model. J. Hydrol. 306(1-4): 127-145.

Muller, D. K., and N. E. Spahr. 2006. Nutrients in streams and rivers across the nation: 1992-2001. USGS Scientific Investigations Report 2006-5107. Reston, Va.: U.S. Geological Survey.

Murthy, R., and P. M. Dougherty. 1997. Effect of carbon dioxide, fertilization, and irrigation on loblolly pine branch morphology. Trees 11(8): 485-493.

NCASI. 2009. Compendium of forestry best management practices for controlling nonpoint sources in North America. Tech.
Bulletin 966. Research Triangle Park, N.C.: National Council for Air and Stream Improvement, Inc.

Negm, L. 2011. Modeling hydrology, nitrogen dynamics, and crop growth for artificially drained cropland. Unpublished $\mathrm{PhD}$ diss. Raleigh, NC: North Carolina State University, Department of Biological and Agricultural Engineering.

Neitsch, S. L., J. G. Arnold, J. R. Kiniry, and J. R. Williams. 2005. Soil and water assessment tool theoretical documentation, version 2005. Temple, Tex.: USDA-ARS Grassland, Soil and Water Research Laboratory.

NRCS. 1995. Riparian forest buffer, 392. Seattle, Wash.: USDANRCS Watershed Science Institute.

Olivera, F., and D. Maidment. 1999. GIS-based spatially distributed model for runoff routing. Water Resour. Res. 35(4): 1155-1164.

Palisade. 1997.@RISK: Risk analysis and simulation add-in for Microsoft Excel or Lotus 1-2-3, Windows version. Newfield, N.Y.: Palisade Corp.

Parton, W. J., D. S. Schimel, C. V. Cole, and D. S. Ojima. 1987. Analysis of factors controlling soil organic matter levels in Great Plains grasslands. SSSA J. 51(5): 1173-1179.

Parton, W. J., J. W. B. Stewart, and C. V. Cole. 1988. Dynamics of C, N, P, and S in grassland soils: A model. Biogeochemistry 5(1): 109-131.

Parton, W. J., J. M. O. Scurlock, D. S. Ojima, T. G. Gilmanov, R. J. Scholes, D. S. Schimel, T. Kirchner, J. C. Menaut, T. Seastedt, E. Garcia Moya, A. Kamnalrut, and J. I. Kinyamario. 1993. Observations and modeling of biomass and soil organic matter dynamics for the grassland biome worldwide. Global Biogeochem. Cycl. 7(4): 785-809.

Parton, W. J., D. S. Ojima, C. V. Cole, and D. S. Schimel. 1994. A general model for soil organic matter dynamics: Sensitivity to litter chemistry, texture, and management. In Quantitative Modeling of Soil-Forming Processes, 147-167. SSSA Special Pub. 39. Madison, Wisc.: SSSA.

Parton, W., W. L. Silver, I. C. Burke, L. Grassens, M. E. Harmon, W. S. Currie, J. Y. King, E. C. Adair, L. A. Brandt, S. C. Hart, and B. Fasth. 2007. Global-scale similarities in nitrogen release patterns during long-term decomposition. Science 315(5810): 361-364.

Pohlert, T., J. A. Huisman, L. Bruer, and H.-G. Frede. 2007. Integration of a detailed biogeochemical model into SWAT for improved nitrogen predictions: Model development, sensitivity, and GLUE analysis. Ecol. Model. 203(3-4): 215-228.

Postek, K. M., C. T. Driscoll, J. D. Aber, and R. C. Santore. 1995. Application of PNet-CN/CHESS to a spruce stand in Solling, Germany. Ecol. Model. 83(1-2): 163-172.

Powell, T. L., G. Starr, K. L. Clark, T. A. Martin, and H. L. Gholz. 2005. Ecosystem and understory water and energy exchange for a mature, naturally regenerated pine flatwoods forest in north Florida. Canadian J. Forest Res. 35(7): 1568-1580.

Prestemon, J., and R. Abt. 2002. Timber products supply and demand. In Southern Forest Resource Assessment, 299-325. D. Wear and J. Greis, eds. Asheville, N.C.: U.S. Forest Service, Southern Research Station.

Preul, H. C., and G. J. Schroepfer. 1968. Travel of nitrogen in soils. J. Water Pollut. Control Fed. 40(1): 30-48.

Reckhow, K. G. 1994. Water quality simulation modeling and uncertainty analyses for risk assessment and decision making. Ecol. Model. 72(1-2): 1-20.

Reddy, K. R., R. Khaleel, M. R. Overcash, and P. W. Westerman. 1979. A nonpoint-source model for land areas receiving animal wastes: II. Ammonia volatilization. Trans. ASAE 22(6): 13981404.

Reuss, J. O., and G. S. Innis. 1977. A grassland nitrogen flow simulation model. Ecology 58(2): 379-388.

Running, S. W., and J. C. Coughlan. 1988. A general model of forest 
ecosystem processes for regional applications: I. Hydrologic balance, canopy gas exchange, and primary production processes. Ecol. Model. 42(2): 125-154.

Running, S. W., and S. T. Gower. 1991. FOREST-BGC: A general model of forest ecosystem processes for regional applications: II. Dynamic carbon allocation and nitrogen budgets. Tree Physiol. 9(1-2): 147-160.

Running, S. W., and E. R. J. Hunt. 1993. Generalization of a forest ecosystem process model for other biomes, Biome-BGC, and application for global-scale models. In Scaling Physiological Processes: Leaf to Globe, 141-158. J. R. Ehleringer and C. B. Field, eds. San Diego, Cal.: Academic Press.

Sahoo, G. B., C. Ray, and E. H. Carlo. 2006. Calibration and validation of a physically distributed hydrological model, MIKE SHE, to predict streamflow at high frequency in a flashy mountainous Hawaii stream. J. Hydrol. 327(1-2): 94-109.

Salas, J. D., and H. Shin. 1999. Uncertainty analysis of reservoir sedimentation. J. Hydrol. Eng. 125(4): 339-350.

Saleh, A., J. R. Williams, J. C. Wood, L. M. Haunck, and W. H. Blackburn. 2004. Application of APEX for forestry. Trans. ASAE 47(3): 751-765.

Saleh, A., X. Wang, M. W. McBroom, J. R. Williams, and O. Gallego. 2006. Validation of APEX for twelve forested watersheds in east Texas. PR0606. Stephenville, Tex.: Texas Institute for Applied Environmental Research.

Sampson, D. A., R. H. Waring, C. A. Maier, C. M. Gough, M. J. Ducey, and K. H. Johnsen. 2006. Fertilization effects on forest carbon storage and exchange, and net primary production: A new hybrid process model for stand management. Forest Ecol. Mgmt. 221(1-3): 91-109.

Sampson, D. A., D. M. Amatya, C. D. Blanton, and R. W. Skaggs. 2011. Leaf area index (LAI) of loblolly pine and emergent vegetation following a harvest. Trans. ASABE 54(6): 2057-2066.

Schlesinger, W. H. 2009. On the fate of anthropogenic nitrogen. Proc. Natl. Acad. Sci. 106(10): 203-208.

SCS. 1972. Section 4: Hydrology. In National Engineering Handbook. Washington, D.C.: USDA Soil Conservation Service.

Shaffer, M. J. 1995. Fate and transport of nitrogen what models can and cannot do. Working Paper No. 11. Ft. Collins, Colo.: USDA-ARS Great Plains Systems Research Unit. Available at: www.nrcs.usda.gov/wps/portal/nrcs/detail/national/technical/nra/ rca/?\&cid=nrcs143_014205.

Sharpley, A. N., and J. R. Williams, eds. 1990. EPIC: Erosion productivity impact calculator: 1. Model documentation. Tech. Bulletin 1768. Washington, D.C.: USDA.

Shirmohammadi, A., I. Chaubey, R. D. Harmel, D. D. Bosch, R. Muñoz-Carpena, C. Dharmasri, A. Sexton, M. Arabi, M. L. Wolfe, J. Frankenberger, C. Graff, and T. M. Sohrabi. 2006. Uncertainty in TMDL models. Trans. ASABE 49(4): 1033-1049.

Skaggs, R. W. 1978. A water management model for shallow water table soils. Report No. 134. Raleigh, N.C.: University of North Carolina, Water Resources Research Institute.

Skaggs, R. W. 1982. Field evaluation of a water management simulation model. Trans. ASAE 25(3): 666-674.

Skaggs, R. W., N. R. Fausey, and B. H. Nolte. 1981. Water management model evaluation for north central Ohio. Trans. ASAE 24(4): 922-928.

Skaggs, R. W., M. A. Youssef, and G. M. Chescheir. 2012. DRAINMOD: Model use, calibration, and validation. Trans. ASABE 55(4): 1509-1522.

Stange, F., K. Butterbach-Bahl, H. Papen, S. ZechmeisterBoltenstern, C. Li, and J. Aber. 2000. A process-oriented model of $\mathrm{N}_{2} \mathrm{O}$ and $\mathrm{NO}$ emissions from forest soils: 2 . Sensitivity analysis and validation. J. Geophys. Res. 105(4): 4385-4398.

Styczen, M., and B. Storm. 1993. Modeling of N movements on catchment scale: A tool for analysis and decision making. Fert.
Res. 36(1): 1-6.

Sun, G., C. Li, C. Trettin, J. Lu, and S. G. McNulty. 2006. Simulating the biogeochemical cycles in cypress wetland-pine upland ecosystems at a landscape scale with the Wetland-DNDC model. In Proc. Intl. Conf. on Hydrology and Management of Forested Wetlands, 261-270. T. M. Williams and J. E. Nettles, eds. St. Joseph, Mich.: ASABE.

Tague, C., C. McMichael, A. Hope, J. Choate, and R. Clark. 2004. Application of the RHESSys model to a California semiarid shrubland watershed. J. American Water Resour. Assoc. 40(3): 575-589.

Thorp, K. R., M. A. Youssef, D. B. Jaynes, R. W. Malone, and L. Ma. 2009. DRAINMOD-N II: Evaluated for an agricultural system in Iowa and compared to RZWQMDSSAT. Trans. ASABE 52(5): 1557-1573.

Tian, S. 2011. Development and field testing of the DRAINMOD forest model for predicting water, soil carbon and nitrogen dynamics, and plant growth in drained forests. Unpublished $\mathrm{PhD}$ diss. Raleigh, N.C.: North Carolina State University, Department of Biological and Agricultural Engineering.

Tian, S., M. A. Youssef, R. W. Skaggs, D. M. Amatya, and G. M. Chescheir. 2012a. Temporal variations and controlling factors of nitrogen export from an artificially drained coastal forest. Environ. Sci. Tech. 46(18): 9956-9963.

Tian, S., M. A. Youssef, R. W. Skaggs, D. M. Amatya, and G. M. Chescheir. 2012b. DRAINMOD-FOREST: Integrated modeling of hydrology, soil carbon and nitrogen dynamics, and plant growth for drained forests. J. Environ. Qual. 41(3): 764-782.

Tian, S., M. A. Youssef, R. W. Skaggs, D. M. Amatya, and G. M. Chescheir. 2012c. Modeling water, carbon, and nitrogen dynamics for two drained pine plantations under intensive management practices. Forest Ecol. and Mgmt. 264: 20-36.

Tian, S., M. A. Youssef, R. W. Skaggs, G. M. Chescheir, and D. M. Amatya. 2013a. Predicting dissolved organic nitrogen losses from a drained forest plantation. Water Resour. Res. 49(4): 19521967.

Tian, S., M. A. Youssef, D. M. Amatya, and E. Vance. 2013b. Global sensitivity analysis of DRAINMOD-FOREST, an integrated forest ecosystem model. Hydrol. Proc. doi: 10.1002/hyp. 9948

Tietema, A. 2004. WANDA (With Aggregated Nitrogen DynAmics): A regional dynamic nitrogen model for nitrate leaching from forests. Hydrol. Earth Syst. Sci. 8(4): 803-812.

Tiktak, A., and W. Bouten. 1992. Modeling soil water dynamics in a forested ecosystem: III. Model description and evaluation of discretization. Hydrol. Proc. 6(4): 455-465.

Tufford, D. L., C. L. Samarghitan, H. N. McKellar Jr., D. E Porter, and J. R. Hussey. 2003. Impacts of urbanization on nutrient concentrations in small southeastern coastal streams. $J$. American Water Res. Assoc. 39(2): 301-312.

USEPA. 1995. National water quality inventory: Report to Congress. EPA-841-R-95-005. Washington, D.C.: U.S. Environmental Protection Agency, Office of Water.

USEPA. 2002. National water quality inventory: 2000 report. EPA841-R-02-001. Washington, D.C.: U.S. Environmental Protection Agency, Office of Water.

Vandenberghe, V., A. van Griensven, and W. Bauwens. 2001. Sensitivity analysis and calibration of the parameters of ESWAT: Application to the River Dender. Water Sci. Tech. 43(7): 295-301.

van Griensven, A., and T. Meixner. 2006. Methods to quantify and identify the sources of uncertainty for river basin water quality models. Water Sci. Tech. 53(1): 51-59.

van Kuelen, H., F. W. T. Penning De Vries, and E. M. Drees. 1982. A summary model for crop growth. In Simulation of Plant Growth and Crop Production, 87-97. F. W. T. Penning De Vries 
and H. H. Van Laar, eds. Wageningen, The Netherlands: Center for Agricultural Publishing and Documentation.

van Schilfgaarde, J. 1957. Approximate solutions to drainage flow problems. In Drainage of Agricultural Lands, 79-112. J. N. Luthin, ed. Agronomy Monograph 7. Madison, Wisc.: ASA.

Vitousek, P. M., D. R. Turner, W. J. Parton, and R. L. Sanford. 1994. Litter decomposition on the Mauna Loa environmental matrix, Hawaii: Patterns, mechanisms, and models. Ecology 75(2): 418429.

Vose, J. M., and H. L. Allen. 1991. Quantity and timing of needlefall in N and P fertilized loblolly pine stands. Forest Ecol. Mgmt. 41(3-4): 205-219.

Wahl, M. H., H. N. McKellar, and T. M. Williams. 1997. Patterns of nutrient loading in forested and urbanized coastal streams. $J$. Exp. Marine Biol. Ecol. 213(1): 111-131.

Wallenstein, M., M. Stromberger, and C. Bell. 2012. Bridging the gap between modelers and experimentalists. EOS 93(32): 312.

Wang, X., M. A. Youssef, W. R. Skaggs, J. D. Atwood, and J. R. Frankenberger. 2005. Sensitivity analysis of the nitrogen simulation model DRAINMOD-N II. Trans. ASAE 48(6): 22052212.

Wang, X., A. Saleh, M. W. McBroom, J. R. Williams, and L. Yin. 2007. Test of APEX for nine forested watersheds in east Texas. J. Environ. Qual. 36(4): 983-995.

Weinstein, D. A., R. D. Yanai, R. M. Beloin, and C. G. Zollweg. 1992. The response of plants to interacting stress: TREGRO Version 1.74. Ithaca, N.Y.: Cornell University, Boyce Thompson Institute for Plant Research.

Will, R. E., D. Markewitz, R. L. Hendrick, D. F. Meason, T. R. Crocker, and B. E. Borders. 2006. Nitrogen and phosphorus dynamics for 13-year-old loblolly pine stands receiving complete competition control and annual fertilizer. Forest Ecol. Mgmt. 227(1-2): 155-168.

Williams, J. R. 1969. Flood routing with variable travel time or variable storage coefficients. Trans. ASAE 12(1): 100-103.

Williams, J. R. 1995. The EPIC model. In Computer Models of Watershed Hydrology, 909-1000. V. P. Singh, ed. Highlands Ranch, Colo.: Water Resources Publications.

Williams, J. R., and R. C. Izaurralde. 2005. The APEX model. In Watershed Models, 437-482. V. P. Singh and D. K. Frevert, eds. Boca Raton, Fla.: CRC Press.

Williams, J. R., C. A. Jones, and P. T. Dyke. 1984. A modeling approach to determining the relationship between erosion and soil productivity. Trans. ASAE 27(1): 129-144.

Williams, J. R., C. A. Jones, J. R. Kiniry, and D. A. Spanel. 1989. The EPIC crop growth model. Trans. ASAE 32(2): 497-511.

Williams, J. R., J. G. Arnold, and R. Srinivasan. 2000. The APEX model. BRC Report No. 00-06. Temple, Tex.: Blackland Research and Extension Center.

Youssef, M. A., R. W. Skaggs, G. M. Chescheir, and J. W. Gilliam. 2005. The nitrogen simulation model DRAINMOD-N II. Trans. ASAE 48(2): 611-626.

Youssef, M. A., R. W. Skaggs, G. M. Chescheir, and J. W. Gilliam. 2006. Field evaluation of a model for predicting nitrogen losses from drained lands. J. Environ. Qual. 35(6): 2026-2042.

Yuan, Y., R. L. Bingner, and R. A. Rebich. 2003. Evaluation of AnnAGNPS nitrogen loading in an agricultural watershed. $J$.
American Water Resour. Assoc. 39(2): 457-466.

Yuan, Y., R. Bingner, R. Williams, R. Lowrance, D. Bosch, and J. Sheridan. 2007. Integration of the models of AnnAGNPS and REMM to assess riparian buffer system for sediment reduction. Intl. J. Sediment Res. 22(1): 60-69.

Zhang, Y., C. C. Trettin, H. Li, and G. Sun. 2002. An integrated model of soil, hydrology, and vegetation for carbon dynamics in wetland ecosystem. Global Biogeochem. Cycl. 16(4): 9.1-9.17.

Zhang, Z., S. Wang, G. Sun, S. McNulty, H. Zhang, J. Li, M. Zhang, E. Klaghofer, and P. Strauss. 2008. Evaluation of the MIKE SHE model for application in the Loess Plateau, China. J. American Water Resour. Assoc. 44(5): 1108-1120.

\section{NOMENCLATURE}

ALMANAC $=$ Agricultural Land Management Alternatives with Numerical Assessment Criteria

APEX = Agricultural Policy Environmental Extender

$\mathrm{BMP}=$ best management practice

$\mathrm{C}=$ carbon

$\mathrm{Ca}=$ calcium

$\mathrm{CN}=$ curve number

CN2 = curve number for Soil Moisture Condition II

$\mathrm{DEM}=$ digital elevation model

DNDC $=$ denitrification-decomposition

DRAINMOD $=$ Drainage Model

$\mathrm{EPIC}=$ Erosion Productivity Impact Calculator

$\mathrm{ET}=$ evapotranspiration

GIS = geographic information system

GLUE = generalized likelihood uncertainty estimation

$\mathrm{GPP}=$ gross primary productivity

$\mathrm{K}=$ potassium

$\mathrm{LAI}=$ leaf area index

$\mathrm{Mg}=$ magnesium

MIKESHE = MIKE Systeme Hydrologique Europeen

MUSLE $=$ Modified Universal Soil Loss Equation

$\mathrm{N}=$ nitrogen

$\mathrm{OM}=$ organic matter

$\mathrm{P}=$ phosphorus

PET $=$ potential evapotranspiration

QUAL2E = Enhanced Stream Water Quality Model

REMM = Riparian Ecosystem Management Model

RUE $=$ radiation use efficiency

RUSLE2 = Revised Universal Soil Loss Equation

(version 2)

$\mathrm{S}=$ sulfur

$\mathrm{SMZ}=$ streamside management zone

$\mathrm{SOM}=$ soil organic matter

SWAT $=$ Soil and Water Assessment Tool

$\mathrm{TMDL}=$ total maximum daily load

USLE $=$ Universal Soil Loss Equation 